\title{
1. Introduction to Comparative Dispute Resolution
}

\author{
Maria Federica Moscati, Michael Palmer and \\ Marian Roberts
}

\section{INTRODUCTORY REMARKS}

This collection explores processes of and issues in dispute resolution, both generally and in specific contexts. ${ }^{1}$ It is comparative in purpose, looking at issues either broadly or with reference to one or more of a wide range of jurisdictions and societies. ${ }^{2}$ Taken together, the book offers new understandings of theoretical, comparative and transnational dimensions of the manner in which societies and their legal systems respond to 'trouble' in social relations (Llewellyn and Hoebel 1941). Where tensions and similar difficulties arise between parties in conflict or competition, they and significant others often explore the possibility of resolving or at least containing the parties' quarrel over their differences. This collection provides a wide range of analyses of how disputes are handled and often resolved ${ }^{3}$ and, in so doing, also brings together scholars of dispute resolution across several generations. Interest in processes and institutions of dispute management has already created an impressive story and generated an important history, but the significance of disputes and conflict in social life means that this interest continues to grow. This collection is a contribution to comparative studies in this field.

More specifically, the chapters gathered here offer valuable new or extended insights into a wide range of issues. A distinctive consideration is given to aspects of the spectrum of responses to disputes, especially those of dispute avoidance and violence. A number of chap-

This chapter is dedicated to the memory of Simon Roberts, an inspirational scholar, 1941-2014.

Thus reflecting two broad styles of comparative legal studies: first, a search for universal processes; and second, the recognition of the importance of cultural distinctiveness.

3 Disputes arise through a reactive social process. An individual (or individuals, or group) perceives that he or she has suffered an injurious experience, and that the problem has been caused by the (mis) conduct of another, blames that party for this perceived injurious experience and institutes a claim against that party. The parties may be said to be 'in dispute' if that claim is rejected in whole or in part. Thus, we see disputes as responsive in nature, created through a process of 'naming, blaming and claiming', and setting in train a process that may or may not lead to the resolution - in whole or in part - of the dispute. Disputing is a complicated process, often involving ambiguous conduct, several substantive issues (not all of which may be initially presented), imperfect recollection, unclear standards, diverging intentions, conflicting values and changes in disputant feelings and objectives over time (Felstiner, Abel and Sarat 1980-81). Gulliver offers an analysis of the emergence of a dispute along similar lines, but holds that it is when differences between the parties cannot be resolved privately and are instead put into the public domain in order to appeal to others that the disagreement becomes a dispute (1979: 75-76). Not everybody would agree with this view, arguing instead that many disputes are negotiated by the parties to a resolution in private settings.

We offer this depiction as a generalized portrayal, and accept that there will be social and cultural variation in the manner in which disputes and disputing are perceived and characterized. 
ters seek to broaden our understanding of processes of negotiation, including the continuing significance of the work of Philip H. Gulliver on the cyclical and developmental dimensions of negotiation (and by extension mediation, and the links in mediation between theory and practice). ${ }^{4}$ The book also provides analyses of a number of specific issues in negotiation, including the problems of lying and deceitful conduct and how best to respond to such misconduct; the preliminary negotiations that may have to take place in preparation for mediation; and the administrative processing of applications by which claims are made in respect of rights to local government assistance. Other chapters point to the value of Gulliver's analysis for family mediation, including its application to dispute resolution involving same-sex partners. In family mediation, conceptual clarity on the nature of the mediation process (its analytically identifiable negotiation stages, cyclical exchanges and patterns of expectations) is of particular importance, given the dynamic reality, powerful emotions and turbulent circumstances that characterize family conflict and family breakdown in particular. The chapters also examine the importance of mediators' domain assumptions and implicit values in relation to the preferences of the parties themselves in a mediation; dispute resolution through mediation of parties who are (or who have been) in a same-sex relationship; the locus of control in mediation; the place of language in mediation, including the difficulties encountered in cross-cultural mediation - in particular, those of translation and interpretation; and the difficulties - such as age discrimination and power imbalances - that are encountered in the increasingly important field of elder mediation.

Understandings are also offered on mediation privilege and its importance for the integrity of process; and on the value of constructing global standards for the regulation of mediation.

A number of chapters analyse changes taking place in and around the court, including examination of the influence on procedural reforms of the contextualizing legal system and legal culture; the manner in which legal traditions and culture impact on the practices of international commercial arbitration; how not only judicial attitudes, but also appreciation by the parties of the value of apology and local community are very important in encouraging out-of-court settlements in Japan; the looming impact of algorithms and other digital tools on the functioning of courts; the problem of the financial costs of access to justice - especially environmental justice in the European context; and how self-representing litigants in the form of skilled 'professional' consumers are surrogate consumer citizens in the limited place provided for civil society actors in China today.

In addition, the practice and study of dispute resolution in the past three decades have involved an expansion through the mixing of primary processes of dispute resolution. Through comparative analysis, contributions to this book help us to understand better the growth of the ombuds as an independent neutral evaluator; the place of restorative justice in dispute management; and the strengths of processual pluralism and the benefits it offers of greater choice for disputing parties, as well as some of the dangers it carries for parties. Chapters also introduce to us the need to consider the significance of the rapid progress towards digitalization of dispute resolution systems - in particular, the issues raised in respect of the regulation of online dispute resolution (ODR) systems. ${ }^{5}$ A number of chapters offer important insights into a range of issues involved in introducing and refurbishing dispute management systems

For a general appraisal of Gulliver's approach see, for example, Caplan (1995).

And, of course, resort to online mediation (eg, via Zoom) has become dramatically necessitated by the coronavirus pandemic that began in late 2019 and early 2020. 
and processes through reform, including the diffusion and transplantation of foreign models (which sometimes also raise issues of normative pluralism). The book provides new and interesting analyses of such changes across a range of jurisdictions and legal cultures.

The study of disputes and dispute processes has been the subject of concern across a broad range of disciplines, and important contributions have been made by scholars working in the social sciences and humanities (in particular, historians). ${ }^{6}$ Despite this rich variety of intellectual perspectives and analytical concerns, and the often complex nature of the decision making that is applied in dispute processes, it is also true that the growing interest in alternative dispute resolution (ADR, but now also sometimes used as an acronym for 'appropriate dispute resolution' $)^{7}$ from the late twentieth century onwards has largely been a matter of legal practice and a feature of Anglo-American law school education, so that legal studies have tended to become the primary home of dispute resolution discourse. Within that discourse, too, thinking has perhaps been overly influenced by the compelling metaphor of refurbished justice assuming the shape of a 'multi-door courthouse', even as ADR as a whole is arguably intended as a flight from the idea of the court as the most important forum for decision making in dispute situations (Palmer 2014). But disputes and the primary forms of decision making - ranging from avoidance to the use of force - are in the main social processes and are often shaped by cultural values, even where they take an explicitly legal form. Indeed, a decision to make a particular process a preferred 'legal option' is itself a product of social and cultural influences. As we have noted, the authors contributing to this book are drawn from a range of disciplines, and those lawyers who have contributed tend to possess a strong interest in the social and cultural dimensions of dispute decision making. They offer fresh insights into the processes of avoidance, negotiation, mediation, umpiring, hybrid processes and self-help.

Over the past few decades in the Anglo-American common law world, as well as in many civilian systems, what is often characterized as the ADR movement has developed into a powerful impetus for civil justice refurbishment. This impetus for reform of the civil justice system reflects a growing appreciation of the value of the processes of negotiation and mediation, and of the need to renovate approaches to adjudication and to innovate by combining primary process into hybrid forms such as 'med-arb'. ${ }^{8}$ Of course, a desire to manage disputes outside

6 On historical analyses see, for example, Auerbach (1983) Bossy (1983) and Davies and Fouracre (1986).

7 The latter term has emerged in response to the characterization in the discourse on ADR systems as 'alternative', given that the extra-judicial processes of negotiation and mediation are in most societies the dominant modes of resolving disputes; and also to the idea that the most appropriate strategy in resolving disputes should be one of 'fitting the forum to the fuss', so that disputants have a choice of process that seems to them the best approach for resolving their disagreement. This re-characterization of ADR has emerged over the course of the past three decades or so, as 'ADR' has become 'institutionalized' or 'bedded in' in various ways (Palmer 2014). This has involved a number of transformations, including 'jurifidication' of processes such as mediation and arbitration so that they become more 'rule-orientated'; the mixing of primary processes to create 'hybrids'; the emergence of issues of regulation in relation to new processes; the incorporation of 'alternatives' to adjudication into the decision making of the courts; the professionalization of the delivery of ADR processes (including the reorientation of legal practice); the unfolding of debates over compulsion and confidentiality in mediation and arbitration; and so on. It might be added here that the comparison of ADR - whatever its precise meaning - continues to be with the formal justice system of litigation and the courts, notwithstanding developments set out above.

8 See the chapter by Menkel-Meadow, 'Hybrid and Mixed Dispute Resolution Processes: Integrities of Process Pluralism' in this book. 
the court and its tunnel track of litigation, or to adjust the manner in which courts operate so that they take into account social realities more effectively in their decision making, was evident long before the advent of the ADR movement from the 1980s onwards. Ideals and practices which stress the virtues of negotiation and mediation as appropriate forms of dispute management were found in many societies before those societies were drawn into the world system (and often still are centrally important today); and they have also formed part of the value systems of various types of local 'community' and social movements which have looked for self-containment and even resistance in times of rapid social change. Especially in the common law world, in response to social issues, courts too have been refurbished - starting with specialized courts dealing with juvenile, family and labour issues, but continuing with the development of commercial courts and extending to various forms of tribunal and arbitration. ${ }^{9}$ A substantial part of the reforms that courts have experienced in the current era of ADR reform has involved extending the judge's responsibilities for judicial case management. ${ }^{10} \mathrm{In}$ the course of these developments, there has also been a shift in focus in both dispute management practice and academic commentary in the analysis of decision making from rules and their application to the processes of dispute management. Moreover, the concern with legal dimensions of disputes is often broadened and influenced by insights gained from the (also expanding) social science literature on disputes or, as is sometimes preferred, conflict and conflict resolution.

One such influence has been the insights offered in social and cultural anthropology. William Twining has emphasized the importance of such insights:

the great bulk of the English language literature on dispute resolution has been stimulated by specifically American concerns and perceived problems. The literature of social anthropology provides some powerful warnings about the complexity of social processes and their relationships to specific cultural and historical contexts (Twining 1993a: 392).

Although the editors of this book did not seek to impose a particular perspective on contributing authors, in looking at disputes and their responses, they have themselves been importantly influenced in both theory and practice by the seminal work of social anthropologist Philip H. Gulliver - in particular, his comparative analysis of dispute management published in 1979: Disputes and Negotiations: A Cross-Cultural Perspective. ${ }^{11}$ In that study, and in a number of separately published essays, ${ }^{12}$ Gulliver examines the processes of negotiation and mediation in very different kinds of society, and argues that these processes of dispute resolution have common trajectories despite the often differing contexts in which they occur. This trajectory consists of two process: one is developmental and propels the parties towards agreement; the other is cyclical, with the disputing parties engaged in information exchange and learning and thereby overcoming antagonisms. By thus coordinating with each other more effectively and overcoming impasse, they thereby move the negotiations forward. Gulliver's approach offers a basis for our general understanding of disputes and dispute management processes, and helps

See, for example, Auerbach (1983). See also Simon Roberts and Palmer (2005: 277-357).

10 For recent insightful analyses of case management, see Simon Roberts (2013), and Reynolds (2020a, and 2020b).

11 See also Gulliver (1963).

12 These include Gulliver $(1961 ; 1969 \mathrm{a} ; 1969 \mathrm{~b} ; 1973 ; 1974 ; 1975 ; 1977 ; 1978 ; 1986 ; 1988$; and 1996). 
analysis in a wide variety of settings. A number of chapters contributed to this volume also see value in Gulliver's approach; and De Girolamo, Kellam, Moscati, Mulcahy, Ng and Marian Roberts in particular look at the value of Gulliver's ideas for understanding the processes of negotiation and mediation, as a core process in ADR. ${ }^{13}$

\section{CONTEXT AND COMPARISON}

This book is comparative in nature and embraces a broad understanding of comparative legal studies. On the one hand, in looking at basic responses to trouble situations, it explores issues found in virtually all societies around the world. On the other, it looks at issues that are raised when 'alternative' or extra-judicial forms of dispute resolution are built into ideas and practices of legal reform. ${ }^{14}$ Contributed chapters engage in and raise questions about issues concerning transplantation; harmonization; and the relation between - and intersection of - the local, the state, the international and the 'other' when considering the management of disputes and developing new and refurbishing existing systems. In addition, the comparative contribution of this volume is informed and strengthened by its interdisciplinarity. The history of the study of dispute resolution shows that, because of the nature of disputes and their resolution, recourse to a variety of disciplines (and methodologies) is often valuable for securing a better understanding of the nature of disputes and the responsive processes by which they are managed. In addition, as many of the chapters in this book illustrate, the role of culture and social context is often very significant. Disputes are developed, perceived and managed in ways that are culturally embedded and socially constructed. Moreover, variations in cultural and social approaches gain particular significance in a globalizing world in which disputants are increasingly drawn from diverse backgrounds. Here, we suggest in passing that Lawrence Rosen's understanding of 'law as culture' and its application to a more general field of 'dispute resolution cultures' provide useful insights (2006).

Although the development of ADR raises interesting and fundamental issues about the nature of law and justice - especially civil justice, and its relationship to law - it is noteworthy that the substantial literature on dispute resolution that has emerged over the past four decades or so has yet to find a firmly established place in mainstream Anglo-American analytical jurisprudence. The latter is an intellectual field that to date has arguably given relatively limited attention to the rise (or re-emergence) of ADR and 'informal justice' 15 that has taken place

13 Two major critiques of his approach have been made by distinguished scholars. The first is that offered by Sally Falk Moore (1995), who argues, among other things, that Gulliver's scheme is too directly borrowed from the track of civil litigation as found in many common law jurisdictions. The second is by Laura Nader, who takes the view that Gulliver's approach is too embedded in intra-societal contexts (and Western understandings), and therefore not appropriate for analysis of international disputes (1995).

14 See also footnote 3 above. The editors share with Foster an expansive vision of comparative legal studies in general as one that should include not only disputes and systems and processes for their management, but also theoretical aspects, single-system analysis, directly comparative analysis, harmonization, legal transplants and mixed jurisdictions, conflicts of laws, geographical and systematic coverage, and problems arising from trans-border transactions (Foster, 2006: 1-2).

15 On the attributes of informal justice, see Palmer and Simon Roberts (2020: Chapter 2), Merry (1993) and Fitzpatrick (1993). 
in particular in recent years in the Anglo-American common law world. ${ }^{16}$ It is an intellectual arena which remains relatively parochial in its focus on, and understanding of, issues of 'doctrine', 'rules', 'law' and 'legal institutions'. It therefore treats extra-judicial processes as much less significant. Perhaps the limited jurisprudential engagement reflects not only this persisting traditional concern with rules and courts, but also the impact of the trenchant critiques of ADR from a 'rule of law' perspective, as discussed further below. Important too is the claim that the authority of the judge in many legal systems is a critical factor. Thus, for example, Kronman argues that the situation in the United States is that the judicial form of dispute resolution has a dominance stemming from the fact that judges are the legal actors who ultimately define the authority that mediators, arbitrators and special masters and so on may enjoy, so that judges and the work they do inevitably retain the position of overriding power (Kronman 1993). It is likely that another factor is simply a felt need to maintain disciplinary boundaries for legal studies and its theorizing, both general and special.

Nevertheless, there are significant strands of engagement that connect the two fields of jurisprudence and dispute management. These include, in particular, Lon Fuller's analysis of processual integrity, leading in due course to the ideal of 'fitting the forum to the fuss'; the rejection by Owen Fiss of 'settlement' (1984); Jeremy Bentham's concern with judicial organization, especially 'natural' systems or procedure; ${ }^{17}$ and Karl Llewellyn's understanding that 'disputes are the eternal heart and core of law' (2008: 79). ${ }^{18}$

One important aspect of Lon Fuller's jurisprudential interests was his concern with legal process and his view that in approaching issues of dispute management, process should not be divorced from outcomes. Underpinning this approach was Fuller's view that the distinction between law and morality had been overplayed, and also his stress on the inherent constraints of various forms of legal and dispute response process. Court-based adjudication may be the most appropriate method of resolving certain disputes among individuals, but it is not necessarily effective in dealing with polycentric disputes, where the dispute may be multi-stranded, involve a range of issues (legal and non-legal), and have long-term consequences for the parties. In other words, legal processes should not be asked to handle disputes and other issues for which they are not best suited. So, processes have an inner problem-solving logic, or 'internal morality', indicating which types of dispute they are best suited for; and in due course this evolved into the idea of 'fitting the forum' to the fuss - that is, identifying the most appropriate response method for handling a particular dispute, a leitmotiv of the ADR movement. In this concern with the distinctive nature of process, he was less keen about (although not wholly opposed to) the idea that they could be mixed, such as in med-arb. His insights strengthened appreciation of the values of mediation, freeing as it did the parties from making decisions in

16 As Twining observed nearly 30 years ago, the literature on dispute processes 'is largely divorced from what is perceived to be "mainstream" Anglo-American jurisprudence as exemplified, on the one hand, by English positivists in the tradition of Bentham, Austin, Hart and Raz, and by their, largely American, critics such as Rawls and Dworkin' (Twining 1993a: 381; see also 382). The position has not in our view significantly changed, although in the text below we note that perhaps a broader vision is now emerging.

17 See Twining (1993a).

18 All four areas are also explicitly identified in Twining (1993a). 
terms of the constraining web of applicable legal rules and enabling them instead to think more about the social, ethical and practical dimensions of their problem. ${ }^{19}$

On the other hand, the perspective offered by Owen Fiss - a distinguished legal theorist with a special concern for adjudicative and procedural matters (rather than general theories of law) - has provided an important foundation for a much more critical attitude towards the broader field of dispute resolution. His particular worry, expressed forcefully in the early 1980s, was that settlement undermines the role of the courts in several ways, but most notably by limiting their ability to contribute to the beneficial development of substantive law. Courts do not just resolve disputes: they also (or should also) function to declare important public values. ${ }^{20} \mathrm{In}$ addition, in settlement negotiations, there is likely no judge to deal with such issues as power imbalances between the parties. Many scholars in the ADR field rejected his arguments. They saw his defence of adjudication by the courts as over-romanticized and considered his understanding of the process of settlement (1) to lack empirical foundation (eg, giving insufficient attention to the managerial role of judges in pre-trial settlement conferences) and to be oversimplified (lumping together in one category various forms of extra-judicial processes); (2) to overlook the issue of whether civil litigation between private parties should be used as a vehicle for supporting public values; (3) to be impractical in the sense that if all civil cases went to trial, the courts would be overwhelmed; (4) to fail to see that forms of process such as community mediation also have the capacity to generate and refurbish public values; and (5) as being too closely based on judicial experience in the United States to be of value for comparative analysis. The combative claims made by Fiss found their way into many texts on ADR, invariably accompanied by sometimes robustly critical responses. Over time, however, some observers have come to see the position taken by Fiss as reflecting the socio-historical circumstances of the civil rights movement and its need for authoritative declarations of liberal values; and others to accept that certain kinds of case are not suited to extra-judicial resolution, but rather require adjudicative decision making, ${ }^{21}$ The debate has also broadened to a consideration of the implications of ADR for 'rule of law' values.

A close associate of Fiss, Judith Resnik (2003) offers a further explanation of his embrace of the value of adjudication. In her view, what was crucial to the thinking of Fiss on adjudication were developments in civil justice reform in the first part of the twentieth century - in particular, the creation of the Federal Rules of Civil Procedure. These were introduced in 1934 in the expectation of simplifying process, facilitating access to courts and dissolving divisions between law and equity. Accompanied by the growth of the federal local judiciary, the Rules were important in promoting the rights-emphasizing ideals of a federal judiciary. This, in

19 The essay by Menkel-Meadow (2000) provides an insightful and extended analysis of the influence of Fuller's work on processual modalities. For Fuller's writings, especially his analysis of adjudication and mediation, see Fuller (2001).

20 As Peters has observed, courts in the United States tend to do both, as there is ' $a$ tension between competing ideas of the primary function of judges and courts: as resolvers of disputes, charged with applying existing legal norms to particular sets of facts; or as makers of policy, tasked with the development of new legal norms to be applied prospectively. In practice, of course, courts tend to do a fair amount of both dispute-resolving and policy-making; the question is which should dominate when these roles conflict' (Peters 2011: 20).

${ }_{21}$ See, in particular, Menkel-Meadow (1985b), Luban (1995), Resnik (2003) and Cohen (2009). A reassessment of the arguments of Fiss is to be found in a special issue of the Fordham Law Review (2009), https://ir.lawnet.fordham.edu/flr/vol78/iss3/ (last accessed 29 July 2020). 
turn, encouraged judges across the country to develop bodies of law promoting social justice through innovations in substantive law, such as anti-discrimination law - a field of particular concern to Fiss. In this way, very positive expectations of adjudication were created, and Fiss argued that this enlightened adjudication was crucial to social order and justice in the United States. Resnik's subsequent scholarship indicates, however, that for a variety of reasons, in recent decades the federal judiciary has failed to deliver on this promise, especially to socially disadvantaged sections of society. Life-tenured federal judges have blocked out such litigants from high-profile adjudication in the federal courts and pushed these litigants instead into less public processes. Resnik concludes that 'policy choices of both judges and lawyers have limited the development of broad constituency support for adjudication' (2003: 176). ${ }^{22}$

Other doubts are expressed about the capacity of law and courts to meet appropriate standards of justice, and the associated moves to the juridification ${ }^{23}$ and privatization of justice. In a perceptive analysis, John Gardner suggests that a major problem that has emerged is 'juridification without legality', and the associated creation of black holes of legality by compulsory arbitration schemes or 'take-it-or-leave-it' boilerplate contracts skilfully designed by multinational and other corporations to avoid legality (Gardner 2018: 9). ${ }^{24}$ Laws have grown so rapidly in number and extent over the past few decades that law is losing its capacity to guide the conduct of ordinary people so that they know when conduct is lawful or not. And faced with a vast corpus of legal rules, officials administering law are unable or unwilling to apply the law scrupulously, but rather exercise unevenly and probably unfairly a vast and unreliable discretion. This problem is exacerbated when extrajudicial procedures are strengthened in their private nature by preventing court assessment - especially judicial review - of the lawfulness of the terms of the agreement between parties in which one party, for example, has imposed its own arbitration scheme that excludes the jurisdiction of the courts. Why should the norms of any such agreement be given legal effect if the institutions administering the law

22 See also Resnik (2015). Galanter additionally points to the introduction of the Federal Rules of Civil Procedure as encouraging many judges in the federal courts to make settlement in the pre-trial conference a feature of the litigation that came before them. He suggests that many of these judges thought settlement preferable to adjudication not only because of administrative convenience, but also because settlement, in their eyes, produced superior results (Galanter 1985: 2).

23 We refer here to the understanding of 'juridification' offered by John Gardner (2018). In using this term, he referred to the proliferation of legal regulation and the many ways in which it pervades our lives. However, the vast corpus of legal and regulatory norms that emerges cannot be understood fully or complied with by ordinary people, and petty officials faced with the proliferation of search norms resort willy-nilly to selective enforcement, so that in effect the rule of law becomes the rule of man. There are parallels here with the analysis offered by Marc Galanter (1992).

24 See also Radin (2013). Increasingly important in some jurisdictions is consumer arbitration, which like consumer mediation (eg, see Zhou 2020) and the consumer ombuds (Hodges et al 2016) - is intended for dealing with disputes that are often small-scale, have diffuse aggrieved parties with the same or similar complaint, and for which litigation seems to be a barrier to rather than an avenue for access to consumer justice (European Union Agency for Fundamental Rights and Council of Europe 2016: 23-55, especially 48-55: Daniels 2019). However, consumer arbitration remains controversial and has not been taken up in Europe to the extent that it has in the United States, where critics point to the many difficulties that have arisen. These problems include limitations on discovery, absence of a sympathetic jury, lack of firm umpiring control and power imbalances between the parties (eg, the repeat player experiences of defendant corporations will impact on such issues as choice of arbitrator). Hollander, in light of these troubles, concludes that the inclusion of mandatory pre-dispute arbitration clauses in consumer contracts should be characterized as contrary to public policy and therefore prohibited (2017). See also McCluskey (2016). 
are prevented from determining what that legal effect is? (Gardner 2018: 7). A better way forward would be to refurbish and support the role of court adjudication by extending legal aid on a much more generous basis than at present and by charging only nominal court fees. ${ }^{25}$ In seeking this renewed role, Gardner sees significant value in the arguments raised by Fiss against settlement (1984), and favours the delivery of justice through the application of law by courts that are subject to the demanding standards of the rule of law, rather than by some other kind of third-party intervenor who is not bound in this way by rule of law values (Gardner 2018: 10-12). The problems of the failure to resist the drift to juridification in the legal system is compounded by the changing role of lawyers, so that they function less as professionals with a commitment to professional responsibilities and rather more as mere service providers. ${ }^{26}$

Others point to particular difficulties for the rule of law posed by the advent of new styles of dispute resolution such as ODR, while not avoiding general issues in the relationship between dispute resolution and adjudication. Timothy Endicott (2016) insightfully deals with the implications of the growth of ODR systems of dispute resolution for rule of law. His analysis argues for explicit extension of the values of the rule of law to include an effective system for the resolution of legal disputes. ${ }^{27} \mathrm{He}$ stresses the value of the widespread use of negotiation for resolving civil disputes, the need to avoid the privileging of adjudication because of its clumsiness and costly nature, and the 'fantastical nightmare of pointless legalism' that such privileging can generate. ${ }^{28}$ ODR has the potential to enhance rule of law values by improving the efficiency of courts so that they are more accessible and offer an effective avenue to justice that is quicker, cheaper, less stressful, more appropriate for the large number of often similar small claims made by large numbers of injured parties in the consumer field (where the facts are likely to be simple and the relevant law straightforward), and more transparent than court proceedings. However, compulsion must be avoided in the design and practice of ODR. Safeguards must be put in place to avoid the arbitrary exercise of brute commercial power and to provide a system that enables disputes to be dealt with in an orderly manner. This is even more important from a rule of law perspective when the courts adopt the use of ODR. So, ODR

25 The importance of legal aid for securing the rights of the least advantaged in society receives renewed emphasis in a perceptive essay offered by Wilmot-Smith (2014).

26 See also the interesting essay by Seana Shiffrin on 'overprivatized' private justice, examining in some depth issues of remedial clauses (also known as liquidated damages clauses) in US contract law. These clauses are subsidiary private arrangements between the parties within their contracts. They identify which remedies should be enforced when the primary contractual agreement is breached. Such agreements replace, by means of agreement between the private parties, decisions that would ordinarily and otherwise be a matter for decision making by the court. They have therefore been traditionally looked on with disfavour by the courts. The need to resist the expanding use of such provisions is seen as important by Shiffrin and others, because such clauses undermine the public interest in this area of law and prevent courts from determining the public significance of legal wrongs (2016).

27 That is, extending the characterization offered by Raz, for example, to include dispute resolution. Raz (2009: 214-18) identifies the attributes of the rule of law as follows: (1) all laws should be prospective, open, and clear; (2) laws should be relatively stable; (3) the making of particular laws (particular legal orders) should be guided by open, stable, clear, and general rules; (4) the independence of the judiciary must be guaranteed; (5) the principles of natural justice must be observed; (6) the courts should have review powers over the implementation of the other principles; (7) the courts should be easily accessible; and (8) the discretion of the crime-preventing agencies should not be allowed to pervert the law. To which Endicott suggests the addition of (at least) one other characteristic: (9) legal disputes must be resolved (2016).

28 See also Luban (1995). 
and other forms of extra-judicial settlement do not necessarily undermine the rule of law: it is the manner in which they are designed and implemented that is the key problematic.

Further jurisprudential analysis may be traced back to the observations of Jeremy Bentham on judicial organization and 'natural procedure'. As Twining (1993a) perceptively emphasized, Bentham's characterization of a natural system for responding to disputes - as Bentham saw it, a system found, for example, in the family - has insights and concerns that can also be observed in contemporary dispute resolution discourse. ${ }^{29}$ Bentham's analysis of the needs of procedural reform saw the natural system, as he characterized it, as an alternative processual model to the 'technical system' - that is, one based on adjudicative decision making in the courts and serving the lawyers' private interests. ${ }^{30}$ In another insightful appraisal of Bentham's ideas, Gerald Postema (2019) ${ }^{31}$ also points out that in Bentham's writings, procedural law is characterized as subordinate to substantive law. It is subservient in that its primary purpose is to give efficacy to substantive law. Nevertheless, procedural law tends to impose conditions on the execution of substantive law. Procedure is accordingly an essential process for the execution of substantive law and possibly therefore also a hindrance to the application of that law. In his analysis of the civil justice system of his time, Bentham concluded that formal legal proceedings were indeed dogged by significant delay, expense, frustration and injustice caused by the complexity and technicality of legal proceedings. The fundamental principle of procedural design should be simplicity. And for Bentham, the simplest form was procedure conventionally exercised by the father of the family in resolving disputes and punishing misconduct within that domestic context: 'the directness and informality of family decision-making makes them most "natural" and the best model and ideal for collective decision-making procedures' (Postema 2019: 338).

This characterization of dispute management within the domestic unit is clearly one that is romanticized, heteronormative and explicitly paternalistic, as well as implicitly authoritarian. However, it is also one that shaped Bentham's view of resolving disputes - especially in the context of parties in long-term relationships and where the presenting issue might in fact be only one of a number of wrongs and rights that have taken place within that relationship. This understanding encouraged him robustly to resist formal complexity in procedural refurbishment, especially of the kind that could lead to the dismissal of cases on procedural technicalities. Rather than tie the judge's hands with due process rules, it was better, in Bentham's view, to guide the judge on how best to handle a case and to give the judge sufficient discretion on how to implement such guidance in the interests of justice. Examples of institutions of that time that Bentham felt showed the value of this approach included the Danish courts of reconciliation and their French counterparts; and, historically speaking, perhaps ancient Saxon concepts of justice based, as Bentham saw it, on ideals of compromise and mutual agreement (Postema 2019: 345-46).

29 See Twining (1993a), especially p. 305.

30 In Bentham's case, the technical system he had in mind was best exemplified by the common law system developed by common law judges and lawyers whose private interests compelled the development of a system too complex and indeed 'technical' to be understood by anyone but fee-collecting lawyers.

${ }_{31}$ This characterization of Bentham's view draws in particular on Chapter 10 of Postema's study, Bentham and the Common Law Tradition (second edition) - in particular, Chapter 10, entitled 'The Judge as Paterfamilias' (2019: 331-49). 
Although much of Karl Llewellyn's career was spent as the Betts Professor of Jurisprudence at Columbia University Law School, he long held a strong interest in the social dimensions of law and in the place of law in society. ${ }^{32} \mathrm{He}$ is reported to have considered himself to be 'half lawyer, half sociologist'. Like Lon Fuller, his work on disputes and their management tended to be seen apart from his more formal and jurisprudential writings. One reason for this in Llewelyn's case may well be that in his work on disputing, he expressed very clearly a 'bottom-up', anti-formalist and rule-sceptic attitude. It was thus far removed from more orthodox jurisprudential concerns. Llewellyn was not keen on orthodox concerns with legal rules and doctrines, and instead sought through empirical examination an understanding of how the law actually worked. In his 'law-jobs' analysis of law in society, he characterized as critically important the issue facing any social group (including, but by no means limited to, the state) of how members go about preventing disputes and encouraging settlement. The 'law' was how the group and its officials handled disputes: 'disputes are the eternal heart and core of law. They do not mark its circumference, but they will always mark its center' (Llewellyn 2008: 79).

Llewellyn and Hoebel's The Cheyenne Way (1941), a seminal legal anthropological study of the law of pre-contact Cheyenne Indians, was an empirical study (though one constructed from informants' memories of past realities) which offered a 'troubled cases' method of researching law - one which would complement the more conventional formal doctrinal approach and the empirically descriptive analysis of legal process. A case-based approach would add to the understanding of how dispute processes actually worked, moving the gaze from 'ought' to 'is'. Moreover, and especially in looking at dispute prevention, a wider vision was also needed. This involved examination of a whole range of social control ideals and practices which worked to ensure the peace. In this sense, analysis of particular issues must be holistic and consider their relationship to the wider social setting. And with this holistic view, we can see that most disputes are settled in one way or another by argument, by wrangling or simply by self-assertion on the one side and submission on the other; or by bargaining, compromising or mediating. The primary business of law is not with these. Law on its dispute side is the machinery of last resort, when these others have failed (2008: 79).

As Twining observes, this leads:

naturally to one of the basic insights and truisms of modern dispute resolution theory that in any given society only a tiny proportion of all disputes are likely ever to reach those institutions we call 'courts', or even those processes which might be included within the sphere of 'litigation'... [so that the study of any] particular dispute settlement method or institution [requires] a realistic demographic picture of all disputes in a society or group in question and how they are presently being resolved (Twining 1993a: 387).

Despite the influence of the cognate discipline of social and cultural anthropology on the development of dispute resolution studies, and early efforts by some legal scholars to generate greater interest in the comparative dimensions of dispute management, ${ }^{33}$ somewhat surpris-

32 For more detailed analysis of the ideas of Llewellyn, see, in particular, Twining (1993a, 1993b) and Mehrotra (2001). The collection of Llewellyn's essays was first published in 1962 and then republished in 2008.

33 See, in particular, the essays in a special issue (2002) of the Willamette Journal of International Law and Dispute Resolution entitled 'The Fiftieth Anniversary Meeting of the American Society of 
ingly, the general discourses of comparative legal studies have also remained predominantly focused on the rules of substantive law and securing justice through the forum of the court. ${ }^{34}$ This approach in the general discourse has persisted even while its proponents have also argued the case for greater contextualization and attention to procedure and to practical issues of reform. Thus, for example, in Andrew Harding and Esin Örücü's edited collection of essays, Comparative Law in the $21^{\text {st }}$ Century - a publication that drew on papers from a workshop celebrating the centennial of the First International Congress of Comparative Law held in Paris in 1900 - it is noted that Lord Goff (a senior judge and workshop keynote speaker) characterized comparative law as the 'flavour of the next century', but also 'added caution especially in the comparative study of substantive law, and proposed instead the reform of civil procedure ${ }^{35}$ by looking at other systems' (Harding and Örücü 2002: viii). This advice, however, was not followed in any of the essays contributed to that volume. ${ }^{36}$

In another edited study inspired by the Paris Congress centenary, Pierre Legrand and Roderick Munday's seminal and splendid Comparative Legal Studies, Traditions and Transitions (2003), the focus is on substantive law and comparative legal studies discourse, with some limited engagement with procedure (Großfeld 2003: 175-77). In the substantial collection of essays in Reimann and Zimmermann's The Oxford Handbook of Comparative Law (2006), the vast majority of the contributions - with some notable exceptions ${ }^{37}-$ do not address disputes and responses to disputes; and those contributing authors who do touch on such issues do not attempt to elaborate in depth on the dimensions of comparative dispute resolution of which they have made mention.

More recently, in the impressive collection of essays put together by Morris Adams and Jacco Bomhoff entitled Practice and Theory in Comparative Law (2012), there is some discussion of case law; but otherwise little or no concern with disputes, or how their management relates to the larger environing legal system. Thus, in the chapter on comparative civil justice contributed by Chase and Varano, despite an intended focus on 'dispute resolution institutions' and a passing mention of alternative dispute resolution (2012: 210), the almost exclusive focus

Comparative Law - Comparative Dispute Resolution: A New Look'. Earlier, in a comprehensive comparative analysis of issues of 'access to justice', Mauro Cappelletti, Bryant Garth and others put together Access to Justice as a four-volume publication (Cappelletti 1978 and 1979). This study explored findings of comparative research into access to justice and reported on the results of the Florence Project of Access to Justice, coordinated by Mauro Cappelletti.

34 We might note here that the comprehensive and thoughtful study of comparative law by Mathias Siems offers some comments on disputes and their resolution; but these occupy only a tiny portion of his observations on the nature of comparative law. It seems that the second edition of his study (2018) covers the disputes ground even more thinly than the first edition (2014).

35 Emphasis in the original.

36 Besson offers a more generalized critique along the same lines when she writes, 'when one knows how scientific methods grew out of the Roman law comparative techniques of legal disputes and their development in the medieval judicial process, it is ironic to read that comparative legal reasoning should now be expected to find its inspiration in scientific methods. Comparative legal reasoning was always a part of the lawyers' methods, whether scientific or not, and well before the empirical turn in social sciences' (2019: 1245).

37 Notably, the essays contributed by Graziadei (2006), Bennett (2006), Gordley (2006), Riles (2006) and Zekoll (2006). In the recently published revised edition of the Reimann and Zimmermann collection (2019), there is little change in this approach: significant exceptions include the essays contributed by Donahue (2019), Graziadei (2019), Nottage (2019), Gordley (2019), Zhang Taisu (2019), Bennett (2019), Riles (2019), Cotterrell (2019) and Zekoll (2019). 
is on courts, lawyers and the adjudicative dimensions of civil justice, with very little said about the overwhelmingly important processes in most societies around the world of extra-judicial settlement of civil disputes as a dimension of civil justice. In the various studies offered in the contributions to The Cambridge Companion to Comparative Law, edited by Bussani and Mattei (2012), we see too a conservative approach:

Comparative law... looks at the law taking into consideration all the possible interactions between the primary sources, be they official or unofficial, dictating the rules and the activities necessary to apply the rules. Therefore, for any comparatist, there is no serious chance of leaving aside any unofficial factor, including those of a geopolitical nature, able to affect the convictions and the legal culture of the rule-setters, the decision-makers and the law-users (Bussani and Mattei 2012: 3).

These 'unofficial' factors do not seem, however, to include ideas and practice of dispute resolution. Thus, in his contributed chapter analysing the 'East Asian' legal tradition, Ruskola - while pointing to the importance of Confucian thinking in shaping Chinese legal culture and a resulting concern with mediation - does not go on to explore in any depth the significant impact of Confucian values on the management of disputes (Ruskola 2012: 262).$^{38}$ This approach also does not give sufficient attention to the fact that in some parts of the world, in the processes of dispute resolution, no legal rules need be explicitly applied; ${ }^{39}$ or to the local understanding that the relevant 'legal' rules emerge from a broad range of general norms in the course of responding to the dispute, as shown, for example, in the study by Comaroff and Simon Roberts of decision making among the Southern African Tswana. The Tswana possess a corpus of rules broadly similar to legal rules found in Western legal systems; but these norms are only loosely applied in dispute management and lack an autonomous and distinctive identity. As a result, the nature of what some observers characterized as 'customary law' on the surface seemed to lack structure and stability. However, the uncertainty in the broader normative repertoire allowed for acceptance of competing constructions of reality that the disputants offered, and for the specific circumstances of the dispute to be addressed (Comaroff and Simon Roberts 1981: 9, 18-19). ${ }^{40}$

If we scratch the surface of comparative legal studies and move away from the general 'textbook' complications, we can see that a strong body of literature has emerged that often

38 The literature on traditional China may be said to see law and legal institutions as something to be avoided as a method of resolving disputes, emphasis instead placed on Confucian values and customary norms. See, for example, Huang (1993). See also Palmer (2006).

39 See, for example, Gulliver's analysis of dispute management without reliance on the courts among the Ndendeuli of southern Tanzania (1970b). See also the study of consumer dispute resolution in contemporary China, showing how many cases of consumer dispute are handled without direct reference to the rules of consumer law, by Ling Zhou (2020).

40 It might be added here that it has also been argued that, given the difficulties encountered in finding a satisfactory definition of law and its rule that would allow for comparative analysis, the field of disputes and dispute handling would provide a more satisfactory field of study. Thus, Abel writes, 'it is a mistake to employ a concept [law] derived from a parochial system of jurisprudence, which had been designed for description and understanding within a particular institutional framework... [disputes are a concept can be applied more widely across disparate societies than any of the definitions of law' (Abel 1973: 223, 225). We might add that a significant aspect of the broader view is that it gives more attention to the social dimensions of a dispute, especially the circumstances of the creation and development of a dispute rather than its more legal dimensions, which tend to be more concerned with the formal resolution of a dispute. 
uses a comparative perspective in the analysis of disputes and their resolution. ${ }^{41}$ This literature often is intended to engage not with the general discourse of comparative legal studies (nor indeed, Anglo-American jurisprudence), but rather with the literature on dispute resolution, socio-legal studies and so on. Several areas stand out as especially strong in growth. Beginning in particular with the insightful study Dealing in Virtue, ${ }^{42}$ Dezalay and Garth encouraged comparative analysis of developments in international commercial arbitration. In their broad-ranging comparative analysis, they explored the emerging tensions between various types of arbitrator - 'the grand old men and the technocrats, the continental professors, and the U.S. litigators, each promoting its own mix of symbolic capital' (1996: 58-59) - and increasing competition between rival places and institutions of arbitration (1996: 44). While Dealing in Virtue is clearly a seminal study within the discourses of arbitration, its wider impact has been more muted. As Schultz observes, in an appreciation of the value of their work:

Twenty years ago, Dezalay and Garth wrote that "International arbitration is an arcane domain, the subject to date of a literature produced mainly by insiders with their own particular understandings". This has not changed all that much. Today one might [still] say that it is "the subject to date of a literature produced mainly by insiders with their own particular agenda" (Schultz 2016) ${ }^{43}$

In recent years, there has been a flourishing of writings with a comparative perspective on international commercial and investment arbitration, and these offer valuable insights. Such studies include The Developing World of Arbitration (2018), in which Anselmo Reyes, Gu Weixia and their contributing authors examine the more recent emergence of Asia-Pacific jurisdictions as regional or international arbitration centres, giving particular attention to the manner in which arbitration law and practice have recently been reformed in Asia-Pacific jurisdictions. It also explores the possibility of an Asia-Pacific model of arbitration reform one that may be distinct from a Western model - and intensified competition between Eastern and Western-based arbitration centres. ${ }^{44}$

Other areas which have adopted a comparative approach, as broadly envisaged, include (but are by no means limited to) the ombuds (and other forms of administrative dispute res-

${ }^{41}$ The editors are grateful to Michael Graziadei for emphasizing in a personal communication the importance of this work, and its potential for broadening the general discourses of comparative legal studies. This does not mean, of course, that Professor Graziadei necessarily agrees with other points made in this introductory chapter. The editors are also grateful for invaluable comments on an earlier draft of this chapter from Simon Palmer.

42 See also Dezalay and Garth (1995).

43 Arbitration has, of course, been important more generally for the development of acceptance of and support for of the idea of resolving disputes through processes that are more specialized, less formal and more focused on party interest than those offered by the court. But the process of arbitration is also often formalized to the point where it is as rule-bound, expensive, subject to delay and so on, as adjudication. The New York Convention for the Recognition and Enforcement of Arbitration Awards 1958 has been a very important development and subject to a considerable body of analysis, both comparative and from the perspective of private international law. The relevant literature tends to overspill into concerns about international commercial agreements, and international investment (including the World Bank's International Centre for Settlement of Investment Disputes system for resolving international investment cases) rather than with processes of dispute resolution.

44 See also the chapter by $\mathrm{Gu}$ Weixia in this book, 'Arbitration in Comparative Perspective'. See further, for example, Ali and Ginsburg (2013). 
olution $) ;{ }^{45}$ mediation inside and outside the court, ${ }^{46}$ consumer disputes $;{ }^{47}$ personal injury $;{ }^{48}$ same-sex couples; ${ }^{49}$ certain legal cultures - perhaps most notably China ${ }^{50}$ and Japan; ${ }^{51}$ and processes of reform and change. ${ }^{52}$

Inclusion of issues of procedure and dispute resolution processes in the general field of comparative legal studies is important for understanding the manner in which the law and legal system actually operate. Concern with substantive law, the structure and function of the courts, the place of lawyers, the manner and extent to which legal systems are mixed, the nature and impact of legal transplantation and so on, are indeed important dimensions of comparative legal studies. The law is important and may well require highly skilled analysis by legal scholars but it is often only one part of a larger, contextualizing system of social order. So, there is more to be compared than rules, the courts as adjudicative bodies, transplantation and so on. This is especially the case when we come to consider the ways in which specific legal systems, traditions or cultures are structured and actually function; or when we compare the manner in which institutions and processes operate. Without a broader vision which, for example, takes into account the fact that legal norms may serve class interests rather than the general public, that in most societies negotiation of interpersonal differences is the norm, and that in the majority of civil justice systems 'most cases settle' rather than go on to be adjudicated, the comparative legal studies picture that emerges is far from complete and may remain to a significant extent doctrinal in ethos. There is a real need also to see how law fits in with other normative frameworks and institutions; the extent to which there is popular social acceptance and use of the law; and the manner in which the legal system works within its societal milieu not only to deliver law, but also to gain the confidence of, and provide access to justice for, ordinary people. Law reform efforts inspired by legal transplantation must be examined for ineluctably transformed meanings of the 'transplants', as Legrand has elegantly emphasized, ${ }^{53}$ so that we need to 'treat rules as actively constituted through the life of interpretive communities' and see 'the negotiated character of rules, that is, the fact that rules are the product of divergent and conflicting interests in society' (1997: 120). Moreover, we need to go on to explore the effectiveness of the transplanted rule or institution, because sometimes the transplanted object introduced and thereby transformed in meaning may remain little more than 'law in the books'. As Graziadei observes, 'sometimes these adaptations actually increase the functionality of the import, but there are also adaptations that are not functional at all' (2019: 466). ${ }^{54}$

45 See, for example, Creutzfeldt (2018), Remáč (2014), Hodges, Creutzfeldt, Steffek, and Verhage (2016), and Dragos and Neamtu (2014).

46 See, for example, Esplugues and Marquis (2015), Ubink (2016) Agapiou and Ilter (2017), and Ali (2018). Hopt and Steffek (2013) offer a major comparative analysis of mediation, but primarily in terms of legal principles, regulatory framework and its location in a wide range of jurisdictions.

47 See, for example, Ali (2013), Hodges, Benöhr and Creutzfeldt (2012), Hodges, Creutzfeldt, Steffek and Verhage (2016), Micklitz and Saumier (2018) and Zhou (2020).

48 See Macleod and Hodges (2017).

49 See Moscati (2015).

50 See, for example, Gu (2012), Liu, Shan and Ren (2016), Fu and Palmer (2017), and Chan (2017).

51 See, for example, Claxton, Nottage and Teramura (2019).

52 Zekoll, Balz and Amelung (2014), Lindblom (2017), and Cadiet, Hess and Isidro (2019).

53 See Legrand (1997).

54 This concern with effective application was one of the purposes of the examination in depth of China's commitment to 'transparency' post-accession to the World Trade Organization in 2001 - not to 
This broader vision will also help us to understand better the complementarity between the formal justice system of the state and the less formal systems of non-state justice. Informal systems of justice may well be effectively reformed by the state in order to encourage management and resolution of disputes at the local level. They may relieve the courts of a backlog of large numbers of filed cases and may offer a system for delivering justice effectively, especially for rural residents who perhaps do not have ready access to competent courts. Thus, some degree of interdependence is generated between the state and non-state justice systems. But at the same time, they may lack legitimacy and accountability in the eyes of many people, suffer from problems of bribery and corruption, and fail to adhere to the standards of international human rights. The manner in which such state and local systems mesh, it might be argued, has in fact been a major concern in comparative legal studies of 'legal pluralism' and rebuts the characterization offered here. But this literature does tend to approach 'legal pluralism' as a discrete issue; and its use of the adjective 'legal' in the term 'legal pluralism' has been robustly challenged on the grounds that inflates the place of law in society. Thus, as Simon Roberts advised:

we need to register the imperial nature of this venture. 'Legal pluralism' has been a term by which lawyers label their own activities, marking out a new sub-discipline of academic law, and identifying a wider area of the social world for their professional operations... [but] where should the new boundary of 'the legal' be fixed? ... With a move away from a conception of law as state law, marking the boundary of legal orders has proved problematic ... State law's commentators have long been garrulous about its attributes; now, graciously embracing others in this discourse, lawyers are seeking to tell those others what they are ... We need to recognize this openly, and be cautious about it for a number of reasons. First, legal rules are so unlike most norms that we risk getting into immediate difficulties if we treat them as the paradigm case. The codified, differentiated form of legal rules, in particular, contrasts sharply with most social norms. The understandings utilized by lay persons about how to behave are not generally like this. They are implicit, and picked up - largely unconsciously - as everyday life goes on. They constitute a largely implicit, loosely constructed, undifferentiated repertoire, rather than plural sets of formulated rules which actors move between in a conscious way. Again, the negotiated orders above state level have a very different character from state law; and understanding of both can be diminished if we aggregate them together (Simon Roberts 2008: 699). ${ }^{55}$

In our argument on the relatively narrow focus of general comparative legal studies, we have indicated that comparative studies of procedures, processes of dispute management and associated institutions have come to be an important area of comparative analysis. However, thus far, this emerging literature remains relatively self-contained and has not yet been drawn into the mainstream discourses of comparative legal studies. In some cases, in looking to the wider significance of findings, the inclination has been and still is to look to socio-legal studies, or to ADR and procedural justice studies, for theoretical inspiration, rather than to engage in comparative legal studies discourse. ${ }^{56}$ This is also the case with many of the chapters contributed to this book.

see transparency as a kind of transplant, but rather to explore in depth the manner in which this commitment had been institutionalised in various areas of the PRC legal system (Fu, Palmer and Zhang 2019). See also, for example, Zhou (2013).

55 See also Simon Roberts (1998).

56 Not surprisingly, there are therefore important arguments put forward for drawing these various fields closer together, as in Creutzfeldt, Kubal, and Pirie (2016) and Bennett (2010). 
The observations made above raise, of course, the difficult issue of where to draw the line between 'comparative law' and 'dispute resolution processes'. The argument offered here is in effect - although changes are clearly now taking place - that any such boundary has in practice been drawn too close to conventional understandings of 'law', especially as characterized in the Anglo-American common law and European civil law worlds. This has tended to exclude the importance of locating formal legal institutions within the broader dispute-resolving context, especially in cultures outside the 'Western' tradition. ${ }^{57}$

\section{SOME ISSUES AND INSIGHTS}

In surveying the field of dispute resolution and, in particular, the legal literature on ADR that has developed in the late twentieth century and beyond, a number of broad issues are evident. These vary in significance, but may require important policy and design decisions at the systems level and in various ways may affect choices made by individual parties.

- For example, how best to balance and integrate judicial and extra-judicial processes, including assessment of the impact of the latter on the status and functioning of the former? Also, to what extent should local and specialized dispute resolution systems be integrated with those of the state, especially those funded to a significant degree by the state?

- Should the state allow or encourage local and specialized systems to develop and to enjoy autonomy, including powers of self-regulation - issues that may also have implications for the way in which the public and private divide is conceptualized and operated?

- How best to provide accessible fora for participants, and especially to avoid creating a situation in which the socially disadvantaged feel they have little choice but to 'lump' or tolerate the injustice that they feel?

- Are disputes seen as the 'property' of the disputants or regarded as involving a significant degree of public interest?

- To what extent (if at all) and in what ways should participation in the processes of dispute resolution, including those offered by the courts, be mandated?

- What role do lawyers play in redefining a grievance ${ }^{58}$ and should legal representation be utilized in extra-judicial dispute resolution?

- Should mediatory third-party intervention be merely facilitative or should it also attempt evaluation and aspire to function as a transformative experience?

- How do dispute processes and their institutions adapt to social change and, for example, confront the problem that success - as gauged in terms of parties' access to the system, and satisfaction with the efficiency and process and the suitability and quality of outcome - may in the longer term create through generating too much demand for the system for it to continue to succeed: 'too much' success, in effect, breeding failure?

- Also important is the issue of where control over outcome should rest - should this be with the parties themselves or with third-party intervenors?

57 See also Samuel (2019: 324).

58 See, for example, Menkel-Meadow (1985a). 
- Indeed, are disputes to be tolerated in society or should there be put in place an ideology of promoting consensus and harmony, even when to do so is at the expense of individual rights?

- How best to ensure enforcement of extra-judicial agreements - even though one of the arguments for extra-judicial process is sometimes that agreements consensually arrived at are intrinsically easier to implement than outcomes imposed by the courts?

- How should digital technology - as used increasingly, for example, in case handling by the courts and in ODR - be built into the design and practice of dispute resolution systems?

- How best to ensure fairness and equality, especially when social identity issues of gender, ethnicity, age and disability might be involved in the dispute?

In looking at these several important and linked issues a little more closely, it is clear that one fundamental issue for debate concerns the relationship between courts and their often primary role as delivering adjudication and forms of extra-judicial resolution that might diminish the role of the courts and legal rules. Indeed, one of the most sustained critiques of ADR as a project of practical reform is that it distracts from legal development, the importance of courts in society and rule of law standards. This concern is taken up most fully in Part VII of this book, where we look at changing cultures and changing systems, and issues of practice and reform, across a range of societies. Local responses may sometimes be mixed with externally imposed or encouraged initiatives. The extent to which expansion (or revival, or both) of the use of processes such as negotiation and mediation, and their outcomes in the form of compromise and settlement, is compatible with rule of law standards and the adjudicative functions of courts may well be an issue in the attempts to refurbish civil justice. And then, what are the difficulties that are encountered when reform efforts explicitly attempt to create a 'mixed process', incorporating ideas and practices located in the values of informal justice into the rules and institutions of a formal justice system? In particular, how are innovations that fuse informal and formal justice values best realized, and what implications does the infusion of informalism into the formal judicial system have for principles such as access to justice and the rule of law?

Indeed, concern with the issue of the impact of informalism on conventional legal institutions and the place of law in the system of justice has been central in basic thinking about ADR since at least the late 1970s. On the one hand, proponents of the use of ADR processes and others ${ }^{59}$ point to the often over-romanticized characterization of litigation and especially the trial process, emphasizing barriers to justice, fairness and equality of treatment created by inequalities in the wealth of the parties; the costs and emotional distress of litigation; and the pain often experienced in the trial process. Trenchant criticism came from Abel (1982), Santos (1982), Nader (1993), Delgado (1988) and Simon Roberts (1983), among others, on the dangers posed by the expanded use of informalism in dispute resolution - that it could exacerbate problems of legal inequality by creating a system of second-class justice for the poorer, more marginalized members of society: mediation for the poor and powerless, and courts for the wealthy and powerful. Others were uncomfortable with expanding the use of mediation in matrimonial cases, asserting that the process of mediation by its very nature disadvantaged women (Lerman 1984) or carried dangers for women if made mandatory (Grillo 1991). Others

59 Such as those wanting to achieve the refurbishment of the civil justice system with case management and early settlement as well as mediation - for example, see Woolf Report 1996. 
argued that the courts must be kept as sites of adjudication. Although his ideas have been subject to re-evaluation after initial criticism, ${ }^{60}$ Owen Fiss, as we have seen above, argued that settlement undermined the need for courts to define and promote core public values in a time of social change $(1984 ; 1985)$. Other scholars have also emphasized the negative impact of the growth of ADR on the work and importance of the courts. ${ }^{61}$

Another important aspect of dispute resolution that is at the core of this book, and that contributors have addressed to different extents - some consciously, others only tangentially - is the relationship between dispute resolution and access to justice. Mauro Cappelletti and Bryant Garth consider access to justice to be:

the system by which people may vindicate their rights and/or resolve their disputes under the general auspices of the state. First, the system must be equally accessible to all, and second, it must lead to results that are individually and socially just (Cappelletti and Garth 1978: 182).

One of the main contributions of the access to justice movement to the study of dispute resolution is the focus on the parties of the dispute as being the primary protagonists and on whom, therefore, the analyst should concentrate. As a consequence, the dispute resolution process must take into account, and be shaped according to, the characteristics and goals of the parties. This is forcefully expressed in the writings of Carrie Menkel-Meadow ${ }^{62}$ and Marian Roberts; ${ }^{63}$ and the observations of Simon Roberts indicate that retaining control has wider implications:

The idea that control over the outcome should be retained by the disputants themselves may be found in association with a number of other objectives. These include a preference for private consensus over external coercion, a retreat from the intervention of legal professionals, and a general desire to shift control over the management of disputes away from agencies of government (Simon Roberts 1983: 540).

Also, as Marc Galanter has suggested, access to justice presents moveable hurdles; and so as more barriers to access to justice are found, more steps to overcome those barriers are made (2010). Thus, access to justice is linked to the perception of the injustice (Felstiner et al 1980-81), to the availability of a variety of methods for the resolution of disputes and to the possibility for the parties in a dispute to make changes affecting their relationship and - where necessary - the community they live in.

Compromise is practised in daily living everywhere and a willingness to compromise is an essential ingredient for social life, especially as it usually carries with it an expectation of reciprocity by the other. ${ }^{64}$ Within any society, "there will always be contests arising not only from conflicting interests particularly economic interests but also from competing moral out-

\footnotetext{
60 Most notably in the special issue of the Fordham Law Review in 2009.

${ }_{61}$ See, for an excellent analysis of these issues, Menkel-Meadow (1995). See also Simon Roberts and Palmer (2005: 45-77).

62 In particular, in Menkel-Meadow (1985a; 1995).

63 In particular, in Marian Roberts (2016). See also Marian Roberts (2014a) and (2014b).

${ }^{64}$ Although such reciprocity may take several forms: see, in particular, the insights into differing forms offered by Malinowski (1922) and Mauss (1990 [1925]).
} 
looks and entrenched beliefs' Hampshire (1999: 77). ${ }^{65}$ So compromise in dispute resolution is a foundational form of social action, and one that takes place in the context of social relationships where there is ordinarily an expectation of reciprocity. Gulliver's developmental model of dispute resolution suggests that in the course of resolving a dispute through negotiation (or mediation-facilitated negotiation), there is a dialectic between the often robust assertions by the parties of their interests and goals and a moderating compromising attitude that (perhaps encouraged by mediator) enables negotiations to proceed ${ }^{66}$ Moreover, as Menkel-Meadow advises, 'by trading both complementary and conflicting items of our own and our counterparts' valuation, we may get something better or bigger than the deal itself' (Menkel-Meadow 2010: 495); and we might add that also sometimes a positive outcome may arise from an entirely new option that emerges and which may not involve a compromise. In addition to this practical imperative, there is often also concern over the moral dimensions of compromises made - is there also an 'honourable' imperative to practise compromise? And are there some compromises so detrimental, for example, to the interests of the party or objectionable in other ways that the concessions which have been delivered render the process or outcome unacceptable? ${ }^{67}$

The work of Stuart Hampshire (in particular, Justice Is Conflict [1999] and Innocence and Experience [1989]) is also important here. Hampshire contends that while 'justice' itself is a universal principle, in our diverse and heterogeneous world we are unlikely to secure consensus on substantive dimensions of justice. The paramount goal in any society (including 'international society') should be to develop fair procedures of justice, so that conflicting interests are fairly decided:

fairness in procedures for resolving conflicts is the fundamental kind of fairness and that it is acknowledged as a value in most cultures, places, and times: fairness in procedure is an invariable value, a constant in human nature. Justice and fairness in substantial matters, as in the distribution of goods or in the payment of penalties for a crime, will always vary with varying moral outlooks and with varying conceptions of the good. Because there will always be conflicts between conceptions of the good, moral conflicts, both in the soul and in the city, there is everywhere a well-recognized

65 Llewellyn's 'law jobs' theory included this understanding, as Twining has recently reminded us: 'all human groups have potential and actual disputes that need to be dealt with if the group is to survive and flourish. The law-jobs theory provides a perspective and set of lenses for asking about the particular ways and techniques these problems are handled specifically within any particular group' (Twining 2019: 37).

66 Sahlins (1965) characterizes three kinds of mutual exchange or reciprocity: generalized reciprocity, balanced reciprocity and negative reciprocity. Each form, further, is seen as reflecting social proximity. Close relationships, such as within the family, are infused with benevolence and generosity, and immediate return is typically not required or expected because of the close relational ties. More distant relationships encourage balanced or negative reciprocity, where an altruistic act - a gift - creates expectations of more or less immediate reciprocity and a fear that there may be no reciprocal act. In addition, the reader might see parallels with Gulliver's analysis of the negotiation process noted earlier, in which there are periods of claiming and antagonism (negative reciprocity) that are brought to a close through compromises that are in effect acts of generalized reciprocity. The negotiations are thereby able to move towards achieving balanced reciprocity - that is, agreement between the parties on the points in contention which the parties can each tolerate.

67 These issues are explored by Menkel-Meadow's review (2010) of the study by Avishai Margalit (2010), On Compromise and Rotten Compromises. For a valuable examination of the relationship between ADR initiatives and 'compromise', especially critiques of the moral value of compromise (and therefore also settlements based on compromise), see also her earlier essay (1995). 
need for procedures of conflict resolution, which can replace brute force and domination or tyranny (Hampshire 1996: 18).

The extent to which, and the ways in which, dispute resolution processes can deliver fair procedures that offer meaningful access to justice for the individual, while at the same time sometimes requiring compromise by the parties in order to secure an agreed outcome and addressing rule of law values and the oft-felt need for efficiency in the delivery of justice, is an issue of fundamental importance. Moreover, there are culturally specific understandings of what is a fair procedure, the nature of compromise and the place of efficiency. The subjective views of the parties will also vary. So, constructing 'tests' or agreeing standards that will enable assessment of fairness and 'just compromises' is itself problematic, and it is difficult to go beyond the conclusion that the 'best' test of fairness is the subjective views of the parties themselves.

The approach taken in most (but not all) of the chapters in this book is analytical rather than prescriptive. We describe the world as our research finds it, rather than offering recipes for successful dispute resolution. The responsive treatment of disputes, as we have noted, typically involves varying and elusive dimensions of social interaction.

The collection as a whole and many chapters individually attempt to explore and enhance understanding by drawing together theoretical and empirical aspects of the various modes of managing disputes. In both theoretical and empirical analysis, it is a struggle to provide accurately the perceptions of the parties and of onlookers, and to assess the extent to which such perceptions differ from what is objectively actually taking place. ${ }^{68}$ And so although generalization is analytically very important, the subjective dimensions of dispute processing may make such generalization difficult to determine accurately.

Disputes, as Georg Simmel emphasizes, are very much a social reality and a form of association or social relationship. Disputes cannot possibly be carried out by one individual alone ([1921] 1955: 13). The causes of dispute or 'disassociating factors' in Simmel's words (ibid) include hate, envy, need, desire - these are the factors that frequently give rise to objectively real or perceived injustices. Societies have developed an impressive and wide range of decision-making responses in order to handle such differences, as the chapters in this book demonstrate so effectively. Both societies and individuals are generally concerned to prevent disputes and to contain them when and where they emerge. Individuals may see an emerging dispute as problematic in a variety of ways - as a potential cause of emotional instability and tension, a waste of resources, a disruption to a valuable social or commercial relationship and so on. In some socio-political systems, the state promotes explicitly a harmony ideology often based on the idea that social stability is more important than asserting rights in a grievance context and correcting injustice and challenging misuse of authority through courts. This ideology may take the form of an explicit encouragement of harmony; or it may take the form of a moral panic complaint about a 'litigious society’ (Nader 1990; Greenhouse 1986, 1989). ${ }^{69}$

\footnotetext{
${ }_{68}$ Issues of perception have been analysed at length in the work of Tamara Relis: see, for example Relis (2009).

${ }_{69}$ It should also be pointed out here that another strand in the comparative literature attempts to consider the issue of the 'litigiousness' - or, at least, the litigation rates - of various societies. We refer in the text above to the sceptical observations by Carol Greenhouse (1989) on the characterization of the United States as a 'litigious society'. Also worth mentioning is an essay by Koen van Aeken (2012) which examines, from a comparative and functionalist perspective, recourse to civil court litigation and
} 
In looking at the social nature of conflict, Simmel also argued that nevertheless, disputes might function in a positive manner, at least from a societal perspective. In reality, 'something which is negative and damaging between individuals if it is considered in isolation and as arising in a particular direction does not necessarily have the same effect within the total relationship of individuals' (Simmel [1921] 1955: 17).

This appreciation of the social functions of conflict is important, pointing us to a perspective in which disputes and the analysis of disputes can operate to reveal social injustice, systematic suppression of rights of the individual and weaknesses in the overall existing system of access to justice. While we must have reservations about seeing disputes in very positive terms, recognition of the value of disagreement is nevertheless important. As Hampshire has emphasized, it is important to 'avoid the suppression of conflicts by a dominant intellect for the sake of harmony' (1989: 189). Instead, it is imperative to understand that in most or all societies, there are conflicting and divergent values embedded in social life; that these may well give rise to repression and conflict; and that developing acceptable ways of reconciling such differences is therefore essential (1983: 166-69). This understanding is an important dimension of the critiques of 'ADR' levelled by Laura Nader and others, that arguments in favour of win-win, inexpensive, quick and interest-focused extra-judicial processes do not serve to create a false consciousness that allows disputes to be sent into avenues that in reality prevent their resolution and the expression of grievance and the assertion of rights. ${ }^{70}$

Authors contributing to this volume do not necessarily characterize 'trouble situations' in the same way: some, for example, use the term 'dispute', while others prefer 'conflict'. In Simmel's work, his lengthy analysis of issues of conflict could be reread by replacing 'conflict' with the term 'dispute' without any loss of understanding (2009: 226-305). Folger prefers to use the term 'conflict' in his chapter, and sees the two terms as interchangeable. Other contributors choose to use the term 'dispute' rather than 'conflict', seeing in broader, more expansive terms the phenomenon of conflict as something occurring in society involving differences of view on fundamental issues and emerging in relationships between social groups. On the other hand, disputes are focused more on specific events, individuals and grievances. In some ways, the choice of terminology is actually not so important - the crucial point being that in either case, there are significant causes of disagreement and strife that are likely to require a response.

alternative dispute resolution in a cross-jurisdiction context. Van Aeken points to the considerable difficulties facing any such analysis, given the need to take into account the social embeddedness of dispute resolution systems and processes, and therefore also to avoid a purely normative approach. He offers the cautious conclusion that the 'elemental structure' of the judicial system seems to be a key factor affecting the degree to which aggrieved citizens look to the formal legal system as a means of redress. However, he also concludes that it is difficult meaningfully to go beyond this, as international variation in frequency of litigation and use of the ADR process do require in-depth analysis of the roles that the contextualizing legal and social institutions impact on, and play in, dispute resolution. It might also be noted that in a comparative analysis of environmental litigation to determine civil liability for environmental claims in the European Union and in the United States, Carmen Garcia-Castrillon concludes that settlement by the parties makes meaningful comparison difficult. He suggests that while it may seem more attractive nowadays for aggrieved parties to litigate in the European Union, nevertheless, 'practice also shows that these cases, on one side of the Atlantic or on the other, tend to end up with settlements, and... a bad settlement is always better than a good trial' (2011: 579).

70 See, in particular, Nader (1993) and Mattei and Nader (2008). 
Although we speak of the 'resolution' of disputes, we see this more as a common aspiration in the dispute management process and do not assume that a resolution will in reality be achieved or necessarily sought. Often, only some aspects of a disagreement between disputing parties will be successfully resolved. Sometimes, the presenting issue in a dispute will not be the real problem and so the resolution process will be misplaced; sometimes, a party will agree to make the concessions that are necessary to arrive at a resolution, but then have a change of heart and re-commence asserting that there is a grievance; or in a multi-party dispute resolution, some parties will feel that the disagreement has been tidied up, while others feel that a tentatively agreed outcome is not satisfactory - so even when a dispute appears resolved, aspects of it may be carried forward implicitly or explicitly for further decision making or resolution. It might also be added here that anthropologists have identified the importance of the dimension of time for understanding disputes, their 'chronic eruptions' and 'the still-to-be-experienced futures' of the individual protagonists and the larger social group (Moore 1995: 32).

\section{CONTRIBUTED CONTENTS}

Throughout most of this collection, contributing authors describe disputants, dispute contexts and dispute management and resolution processes either in general terms or with reference to specific legal cultures. The chapters collected here should be thought of as contributions by experts in the field whose offerings primarily reflect their expertise, rather than as intending explicitly to assist in creating a comprehensive picture of the field. However, it may be the case that some readers will see the book as offering fairly broad coverage of, and a wide variety of perspectives on, the dispute resolution field.

The book begins with an examination of some of the main processes of decision making used to deal with disputes. These modes of dealing with disputes range from avoidance at one end of the spectrum to self-help and violence at the other. Much of the rest of the book deals with the more conventional responses of negotiation, mediation and umpiring, and of related reforms intended to facilitate access to justice through the adaptation and refurbishment of these basic processes. The final part examines reforms across a wide range of jurisdictions.

How should we characterize modes of dispute and responses to emerging disputes; and why and how do some disputants avoid confrontation, whereas others resort to violence and other forms of self-help? Here the broader context is the spectrum of possible responses to trouble. As Nader and Todd have characterized the spectrum:

Most societies have access to several procedures to deal with trouble ... The crucial variables are the presence or absence of a third party and the basis of the third party intervention and the type of outcome (if any). The same basic procedural modes are used worldwide in attempts to deal with grievances, conflicts or disputes: adjudication, arbitration, mediation, negotiation, coercion, avoidance and "lumping it" (Nader and Todd 1978: 8-9).

So, in Part II, we look at some important aspects of disputes and responses to disputes. Special attention is paid to issues that are not ordinarily given detailed, focused analysis in the examination of responses: namely, the two ends of the response spectrum - avoidance and violence. Avoidance (including dispute prevention) often involves a considerable degree of self-control; while resort to violence may often involve a considerable loss of self-control. In another sense, however, they may share a concern simply to bury or deflect a dispute, eschewing modes of 
dispute treatment that might more readily allow for a readjustment and renewal of relationship. The chapters contributed by Fiona Cownie and Anthony Bradney, and by Michael Palmer respectively, deal with the processes situated at the two ends of the spectrum: avoidance and violence. $^{71}$

Donna Coker extends our gaze, examining the use of restorative justice responses to intimate partner violence (domestic violence). Coker's comparative research identifies the strengths and weaknesses of various restorative and transformative approaches. She further describes a 'changing tide' in feminist thought, from initial opposition to a recognition of the value of specialized restorative practices as an alternative to more punitive and frequently less effective options.

Joseph Folger's chapter looks at fundamental issues in the relationship of theory and practice in the conflict field, and their implications for control of process and outcome in third-party expert intervention in disputes. Drawing on his academic and professional experience in North America, ${ }^{72}$ his study points to the importance of how third-party intervenors such as mediators can define a disputing situation in terms of their pre-existing theoretical perspective. The manner in which an intervening third-party responds to and manages a dispute ${ }^{73}$ is often more significantly shaped by these 'antecedent ideological commitments' than by the nature of the dispute and the interests of the parties as seen by the parties themselves. While these theoretical assumptions may be invaluable for an intervenor's general understanding of the nature of disputes and conflict, they may not necessarily be a good fit with the choices that disputants would themselves like to make or with the objectively optimum outcome to the dispute. Instead, they privilege the preferred evaluating narrative constructed by the intervenor and may well prevent prioritization of the parties' perspectives. Thus, there is a need for greater ideological self-awareness on the part of intervenors. This also has implications for the training and development of mediatory skills, because the immersion in such skills may reinforce rather than relieve this fundamental problem. There are clear parallels in the analysis offered by the chapter with the contrast between evaluative and facilitative mediation.

The chapter contributed by Palmer looks at self-help, especially violence, as one of the responses to disputes found in many societies. The chapter argues that violence - like avoidance and prevention - is given insufficient attention in the legal discourses on dispute resolution, where the focus is ordinarily on the more legally acceptable responses of negotiation, mediation, adjudication and arbitration. Nevertheless, in the general literature on disputing and social control, there is a broad and impressive literature on violence. From social anthropology, we learn of symbolic violence in some societies, such as the Eskimos' use of competitive singing to express anger and hostility, rather than physical violence. And the chapter suggests

71 Very helpful characterizations of the processes of negotiation, mediation and umpiring are provided in a number of places in the literature. These processes are dealt with in some length in Palmer and Simon Roberts (2020). On avoidance see, for example, Cownie and Bradney (2000).

72 It might be added here that in many jurisdictions, mediators are explicitly enjoined not to give advice (eg, because of the potential conflicts of interest of the parties), but this does not mean that their views cannot be insinuated. Whereas the giving of information is acceptable in mediation, there is often a thin line between information and advice giving. Nevertheless, his observations would be useful for the analysis of the relationship between the mediator's theoretical perspective and the practice of dispute resolution in China, informed as it often is by ideologies of Chinese socialism and Confucianism: see Fu and Palmer (2017).

73 Professor Folger himself prefers to use the term 'conflict'. 
that sociologist Randall Collins' ideas about violence offer valuable insights into physically forceful conduct in the context of a dispute. Although it might be argued that Collins' analysis underplays the importance of the structural and cultural contexts of violence, his work offers invaluable insights. Violence is a dramatic response, often attracting a great deal of public attention but, empirically, is not at all common. In tense situations between disputants, what is important is the way in which the parties move ever closer to the mouth of a tunnel of violence into which they are drawn, perhaps encouraged by onlookers. Violence is inflicted by one or both parties. After emerging from the tunnel, the parties may have only a very imperfect recollection of the traumatic experience through which they have just passed.

In Part III, we look at issues in the analysis of negotiations as a form of response to a dispute. The problems created by lying and deceit in negotiation are important, as Simmel stressed. For Simmel, lying is conscious conduct which creates a misconception or error in understanding that undermines the reciprocal knowledge that is essential to social interaction (1950: 312-16). The lie corrupts access to knowledge and understanding in a way that often enhances the offending party's power and control. ${ }^{74}$ In a history of ADR literature, this is an issue going back at least as far as James White's seminal essay on 'Machiavelli and the Bar' (1980). Specifically, what sort of impact does lying and other forms of deceptive conduct have on the process and progress of negotiation, and how might the parties disadvantaged in this way best protect themselves or be better protected by regulatory reform which promotes ethical standards and enhances enforcement of such standards? In this book, the chapter contributed by Clark Freshman looks at the first kind of response, analysing in depth negotiation interaction for indicators of such deceptive conduct. He suggests that negotiating parties need to be more aware - more than they often are at present - of the incidence and impact of deceptive conduct in negotiations, and how difficult it can be to 'learn the science and craft' of negotiating effectively despite the use of lies by the other party.

Debbie De Girolamo's chapter, informed by the 'dramaturgical' analysis of social interaction developed by social psychologist and sociologist Erving Goffman, examines the negotiation conduct that takes place in the early stages of mediation in which the parties are legally represented - specifically, each party's opening statement. She reveals in her chapter how, in their exchanges of information, the legal representatives convert the process into a game of strategic manoeuvring. Competitive moves and responses to such moves may create barriers to progress, but may also reset the stage so that the parties can move forward with the genuine exchange of ideas encouraging them towards resolution of their dispute.

As indicated above, the editors of this book see the work of Gulliver as seminal. Maria Federica Moscati's chapter looks at the negotiated resolution of disputes between same-sex disputants and examines, through the application of Gulliver's cyclical and developmental analytical constructs, how such resolution efforts might be complicated by the legally ambiguous or uncertain context within which the resolution must be negotiated. She concludes that this context is indeed an important element in any explanation of the shape and progress of the negotiations seeking to resolve such disputes, alongside other factors such as politics of the body, parenthood and family relationships.

In her chapter, Amy Kellam explores issues of law and negotiation in international dispute resolution. She notes that, despite a growth in legalistic processes over the course of the twen-

74 See also Gilsenan (1976). The principal work on issues of ethics and negotiation is Menkel-Meadow and Wheeler (2004). 
tieth century, a strong preference for negotiated outcomes remains; and that even legalistic methods of international dispute resolution remain strongly influenced by negotiative models. Gulliver's insights on negotiation, developed through comparative analysis, provide important understandings of the processes of international dispute resolution. These suggest a complex picture in which strategic preferences and disputing styles move back and forth, both in specific disputes and more generically over the course of the past century or so.

Patricia Ng's contribution looks at the relationship between homeless applicants and bureaucrats in the homeless application enquiry process. Her analysis is informed by Gulliver's insights into the negotiation process - in particular, the developmental dimensions of negotiation. The chapter suggests that there is what Gulliver calls an 'essential patterning' during each negotiation phase and this - as well as Gulliver's insights into the transitional phases of negotiation - helps us to gain a better understanding of the ways in which a homeless person makes an application for emergency housing in London, sometimes succeeding, sometimes not. Her examination also draws inspiration from Felstiner, Abel and Sarat's 'naming, blaming and claiming' paradigm of dispute development (Felstiner et al 1980-81).

Mediation is the subject of the chapters in Part IV. The radical and general transformation associated with the emergence of the ADR movement in the West in the early 1970s - transformations of language (eg, 'cases' into 'disputes'; 'clients' into 'parties'), of focus of discussion (away from formal justice towards the possibilities of ADR processes) and of policy and practice developments - have been well documented by scholars (Astor and Chinkin 2002; Menkel-Meadow et al 2018; Palmer and Simon Roberts 2020). Of the three primary dispute resolution processes identified by Palmer and Simon Roberts (1998), mediation has dominated both practice developments and the research and scholarly literature. It represents the modern application of an ancient and universal method of settling quarrels that continues to expand in range and approach across a wide variety of fields of practice. When mediation emerged in the Anglo-American common law world in the latter half of the twentieth century to fill a space, hitherto unoccupied, which none of the existing services - whether lawyers and the courts on the one hand, or welfare, advisory or therapeutic interventions on the other - could in their nature have filled, there was a pressing need to clarify intervention boundaries. This has become ever more urgent given the growth of hybrid dispute resolution processes which, though arguably promoting creativity and innovation, also increase role and function confusion and intervenor control.

These mediation practice developments preceded, on the whole, attempts to clarify and conceptualize the distinctive nature and purpose of this new and evolving mode of dispute resolution, where authority for decision making lies with the parties themselves. This was a project that involved defining mediation's fundamental principles (voluntariness, impartiality, confidentiality and procedural flexibility), clarifying its core elements as a triadic process of dispute resolution; recognizing disparate models and styles of practice; as well as identifying the skills of effective practice.

Each of the chapters in this part - drawing on research, on the rich interdisciplinary body of literature that informs the field, as well as on direct practice experience - advances this clarification endeavour by focusing on one or more of these essential components in order to draw attention to what is distinctive about mediation. Each chapter explores, in a variety of contemporary manifestations, those features of mediation that define its fundamental characteristics and clarify its essential difference from other interventions. 
Contemporary developments, particularly of hybrid forms, increase the already recognized complexities of mediation: its lofty goals (with regard to the parties, the process and the outcome); inherent ambiguities and tensions of the mediator role itself (aiming to achieve the resolution of the dispute with a corresponding lack of power to do so; the intermediate position of the mediator between the parties); and the objectively difficult circumstances of acrimony and powerful emotions in which negotiations typically occur (Kressel 1985).

Linda Mulcahy's chapter locates mediation in its broadest conceptual setting as an ancient process informed by seminal writings on the subject of dispute resolution, both formal and alternative modes. In contrast to the dyad of negotiation and the imposed decision making of adjudication, mediation provides a different dynamic and approach to procedural justice, vesting decision-making authority with the parties in a triadic process characterized by both its procedural flexibility and its variety of possible outcomes. She draws attention in particular to the anthropological research of Gulliver, celebrating his exemplification of the most sophisticated cross-cultural, theoretical delineation of mediation among modern Western theories in the dispute resolution canon. In doing so, she highlights his success in uniting both academics and practitioners in the field.

While acknowledging Gulliver's own recognition of the need for more research, Mulcahy also points to those socio-legal critiques that address the need for a greater focus on the structural and normative dynamics - in particular, cultural and gender dynamics - that have a decisive impact on power relations between disputing parties, particularly in the context of family mediation. In aligning the Gulliver model of mediation with the facilitative approach of the mediator (where the mediator adopts a non-directive approach to facilitating the parties' own efforts to negotiate a jointly agreed outcome), Mulcahy contrasts this with evaluative mediation: a hybrid process where three analytically distinct and contradictory roles are conflated - that of mediator, adviser and arbitrator. Here the mediator may make recommendations for settlement or provide an assessment of the relative merits of the case, thereby shifting the central locus of decision-making authority from the parties to the mediator. In drawing attention to contemporary debates about whether such a process can be conceptualized as mediation at all - as well as to the role of lawyers who, in initiating such hybrid processes, expand their colonization of mediation - Mulcahy's chapter serves to demonstrate what is critically distinctive about mediation.

Marian Roberts' chapter further explores the application of Gulliver's delineation of mediation to the field of family disputes. This is a process in which mediation is understood to serve the negotiation process - itself an integrated cyclical process of communication exchange within a linear process identified by sequential phases of negotiation. Roberts describes how progressive movement towards settlement can be achieved by means of the effective orchestration of the process by the mediator, whose primary function is to ensure both constructive communication exchanges between the parties and the management of the difficult transitional phases of the process - in particular, away from early hostility, insecurity and entrenched positions towards an improvement of understanding and the lessening of conflict and stress through enhanced learning and understanding. Gulliver's model demonstrates how mediation as a dispute resolution process has a negotiation and psychological coherence which makes possible both settlement of the dispute and the improvement of interpersonal relations, often seen to be alternative or incompatible objectives. Roberts describes the ways in which this processual model, in uniquely informing mediation practice in the context of the breakdown of 
intimate, highly charged family relationships, exemplifies the beneficial integration of theory and practice.

Given the centrality of effective communication exchanges in mediation, the chapters of Lesley Allport and Brooke Townsley focus further on language and its significance in mediation. Allport's empirical data sheds light on the reciprocal impact of differential language use in giving meaning to the different roles of lawyers and mediators in the civil justice system in England and Wales - of particular relevance where dispute resolution processes are combined in hybrid forms such as med-arb. Her linguistic analysis shows that while values - for example, of justice and fairness - may be shared by lawyers and mediators, these cannot disguise essential differences of role. Allport's studies reveal the critical importance of language for identifying distinctive professional roles, especially in the context of hybrid practice. Her chapter furthers understanding of the importance, in the pursuit of justice, of the clarity of dispute resolution boundaries and of the distinctive nature and purpose of mediation.

Brooke Townsley's chapter draws on his European research, Understanding Justice (Townsley 2016), to explore the central significance of language and the importance of communication both in interpretation and in dispute resolution processes, in respect of mediation in particular. He highlights the vital distinction between the purpose and manner of communication exchanges in the mediator role and that of the role of the interpreter in mediation. While both roles involve recognition of the current challenges that face communication exchanges - challenges of social, cultural and linguistic complexity in particular - Townsley's chapter identifies the need for and the manner of constructive collaboration between mediators and interpreters, in order to better understand and address the complexity of these challenges in the communicative setting. He draws attention to some common, yet largely problematic practice models that mediators currently adopt to avoid involving interpreters, including the dual mediator/interpreter role, which can place a heavy burden on cognitive capacity and risk compromising the core mediation principles of confidentiality and impartiality.

The chapter identifies a model of practice that would enable mediators to make the most appropriate and constructive use of professionally trained and certified interpreters. In circumstances of increasing language diversity, such an approach would both protect the integrity of the mediation process and enhance the increasing deployment of mediation in cross-cultural and cross-border disputes.

The contributions of both Kenneth Kressel and James Wall draw on research into the elusive yet vital subject of identifying which mediator behaviours constitute effective practice. Kressel's focus is on the mediator's style: those behaviours, cognitions (explicit and implicit) and goals which may best achieve positive results in mediation, in respect both of problem solving and of party satisfaction. Kressel identifies two principal sources of mediator stylistic behaviour - the formal and the implicit (unconscious) - and considers the influence on these of mediator goals within the context in which mediation is practised. Yet difficulties arise not only because of stylistic flexibility and the striking variance that is apparent between formal, conscious styles and tacit implicit understandings; but also because of the lack of any current meaningful taxonomy of mediation situations against which to measure stylistic behaviours.

To remedy the lack of robust knowledge as to what constitutes competent practice, Kressel recognizes the need to promote the engagement of expert mediation practitioners in reflective, case-based research. This research would require there to be systematic protocols for case reflection, in vivo observations of mediators at work and comparative studies of mediator 
cognitions in different settings. As Kressel notes, the struggle for theory and research to catch up with practice continues.

Wall's research into civil case mediation examines the link between mediator thinking and mediator behaviour, the interaction between the mediator and the disputants (by no means passive recipients), the legal context and the case type involved (eg, personal injury and medical malpractice cases in this context). His findings reveal the parallel planes, both rational and intuitive, along which mediator thinking moves in relation to the behaviours of mediators and their goals - whether settlement seeking, client satisfaction or perhaps an unexpectedly major goal of seeking repeat business. In examining the impact of different mediator behaviours, Wall identifies those behaviours that are effective in yielding agreements, with assertiveness (manifest in a variety of strategies) effecting more success in achieving agreements in civil case mediation compared to other styles.

Wall does not extrapolate to other areas of mediation practice, but with Kressel recognizes the need for more research into mediator behaviour to better understand what constitutes effective practice. Yet the limitations on current research are acknowledged: empirical difficulties of restricted time and funding, and of achieving direct observation and recording of the complex, often unpredictable dynamics and interactions of actual practice.

Another perspective on identifying and protecting competent practice is provided by Nadja Alexander's chapter, which focuses on mediation's professional regulatory framework. She moves away from exploring regulation from a conventional positivist approach to a fresh approach that takes on the characteristics of mediation's own negotiation process. Such a regulatory 'ecosystem' would take account of mediation's procedural flexibility, its diversity of practice models and its potential for creative and innovative approaches for addressing disputes. The vexed question she seeks to address is how best the field of mediation can be regulated so as to avoid both its co-option by lawyers as a specialized form of legal practice and compromising those very qualities that make it of attraction to users.

In her wide-ranging examination of a variety of regulatory frameworks for mediation in the United States, Europe, the Middle East, Australia and the Far East, Alexander answers the question by identifying those factors that would allow for the development of a worldwide, pluralistic and ethical regulatory framework in which regulation would be viewed through a social, cultural and legal lens.

This is a contextual view of the regulation of mediation informed by a shift of focus from outcomes to process, away from a statutory, formal, hierarchical model to a broader, more democratic concept of regulation that involves consensus and the collaboration of all interested stakeholders in exercising greater party and community autonomy in agreeing a range of regulatory instruments and interactions. In this way, the regulation of mediation is reimagined, in theory and in practice, to embody an ethical dimension as a dynamic part of the regulatory framework. This is a view of regulation for this nascent profession that encourages collaborative effort in the setting of standards and voluntary compliance, and which reflects its responsibility to all members and to the public.

Gary Meggitt's chapter propounds arguments for identifying the privilege of mediation communications as one of the process's defining features in common law jurisdictions. The main justifications for considering such a privilege to be essential to mediation are that it fosters open and frank communication exchanges; it protects the mediator's independence; and it clearly distinguishes the function of litigation from that of mediation. This chapter 
examines the components of mediation privilege and compares its status in the jurisdictions of the United States, Hong Kong, Australia and England and Wales.

Meggitt argues that the main justification for mediation privilege is that, by protecting the integrity of the process and establishing the centrality of party control over decision making, it lies at the heart of the very nature and philosophy of mediation.

How these values - and in particular, the extent to which effective participation in party decision making - can be 'protected' is further explored by Dale Bagshaw in her examination of the application of mediation to the complex and highly specialist field of elder mediation. As this is an area of practice where power imbalances may be endemic, given the prevalence of ageism and different and/or diminished levels of capacity, and where elder abuse and discrimination is not uncommon, pre-mediation screening for suitability and specialist knowledge and training in the field are essential for there to be competent and ethical practice in this challenging arena. The main focus of this chapter is on how best to balance protection and respect with the principles of impartiality, equality and inclusion. Examples show how elder mediation can be effective where models of practice integrate support, address multi-party participation (eg, carers, family, advocates, professionals), and ensure that the voice of the older person is both heard, directly or indirectly, and respected.

Just as Gulliver's seminal analysis of mediation exemplifies the theoretical and experiential dynamics of its interlocking processes, so too these chapters illustrate the interwoven nature of theory and practice for informing understanding of mediation in its variety of evolving and challenging applications.

Part V considers umpiring in the broad sense of authoritative third-party decision making, and therefore encompassing private and public processes. The chapters show the heterogeneity of umpiring. Technology, judicial settlement, judicial review and involvement of professionals bring arbitration and litigation closer to hybrid and mixed process. So questions arise concerning access to justice and the reasons for shaping and reshaping umpiring.

Part V opens with a comparative analysis of judicial conflict resolution in Italy, Israel and England and Wales. Authors Michal Alberstein and Nourit Zimerman define 'judicial conflict resolution' as 'any activity of a judge that aims to promote substantive agreement between the litigants about a resolution that ends the litigation neither through judgment on the merits nor through technical disposition'. Although the three legal systems examined in their chapter share similar civil justice system processual dysfunctions and, to varying extents, possess administrative and legislative measures intended to encourage settlements, important differences are also to be found. The reasons for such differences are to be located in the manner in which legal systems and their legal cultures frame litigation and settlement. Together with access to justice discourse, the authors examine the manner in which the intended aim of the legal systems is to achieve efficiency and overcome court backlogs.

The chapter by $\mathrm{Gu}$ Weixia explores some comparative issues in the processes of arbitration in various areas around the world, including Asia, Europe, the United States and Australia. The author focuses on the relation between ADR and arbitration (with particular attention to the manner in which the different legal systems position arbitration within broader ADR discourse), approaches to the creation and activity of arbitral tribunals, and the approach to the hybrid process of med-arb. Through the analysis of these three aspects, Gu Weixia explores the impulse towards juridification of arbitration found in the legal systems analysed, and 
concludes that cultural and traditional factors influence the manner in which different legal systems approach arbitration practice.

A historical perspective drives John Haley's in-depth analysis of dispute resolution in Japan. The author suggests that in Japanese society, there is a propensity for people to settle disputes through negotiation and to avoid third-party intervention. The reasons for this orientation are various: cultural, managerial, historical, structural and rational. Together with a tendency to ask for and to offer apology, Japanese appreciation of community - including the importance that the village and the local community have for society and the individual - and the structure of the judiciary explain why out-of-court settlements are sought and achieved.

The chapter by John Morison and Adam Harkens considers the role that technology plays in dispute resolution and addresses the provocative question: 'It is certainly possible that the role of lawyers might be augmented by machines but could they, or even judges, be replaced by robots?' Looking at the move from ADR to ODR would perhaps prompt a potentially affirmative answer. ODR has indeed the potential to develop a new approach or system of dispute resolution. However, the authors suggest that a more cautious and sceptical approach is needed in assessing the impact of algorithms and other digital tools. The social nature of law, the authors point out, represents a resistant force to legal processes managed by machines. In particular, looking at judging, if on the one hand, technology can enhance managerial systems, on the other hand, ultimately human values cannot be excluded from the picture.

With a focus on access to environmental justice in the European Union, Áine Ryall's contribution comprehensively addresses the controversial issue of the cost of access to such justice. The chapter starts by critically analysing the legal framework governing access to justice in the European Union. It then moves to the case law of the Court of Justice of the European Union (CJEU). Regarding costs, the approach taken within the European Union is that judicial review procedure on environmental law should not be 'prohibitively expensive'. However, the language used by the law leaves room for discretion and vague interpretations of what should be considered 'prohibitively expensive'. Thus, the CJEU seems to have developed a jurisprudence which - infused with the principle of access to justice - overall suggests that litigants should not be prevented from filing a case because of the costs.

Part V ends with a detailed ethnographic account contributed by Ling Zhou concerning the resolution of consumer disputes in China. It offers a different understanding of the relation between litigants in person and access to justice, showing that sometimes in China, lack of representation by a lawyer does not necessarily constitute a barrier to justice. Dr Zhou's chapter explores the experience and the role of consumers who develop particular expertise in handling consumer disputes. Although not legally trained, these 'bottom-up' figures are considered to be consumer 'professionals'. These specialists show considerable expertise in consumer issues and processes of consumer dispute resolution, especially litigation and litigotiation, and are often regarded highly by other consumers and by the judiciary. Because legal representation is difficult and legal aid is not provided for this type of dispute, Zhou concludes, 'the emergence of the professional litigants is a plus for consumers' access to justice, particularly, their skilled negotiations and use of court procedures do help in the vindication of consumer rights'.

Naomi Creutzfeldt begins Part VI by exploring comparatively the development of the ombuds over the past two decades and addresses the question: 'does the rapid spread of the ombuds bring with it a slow demise of its original purpose?' Through an in-depth analysis of private, public and organizational ombuds in a variety of legal systems, Creutzfeldt suggests that the spread of the ombuds should be considered as a set of dispute resolution mechanisms/ 
means which are supple enough to adapt to the specific needs of the existing legal system. With a tendency to assist consumers when the legal system is deficient in meeting their needs, the ombuds is also useful in reflecting a renewed conceptualization of the relation between the state and the citizen.

Theo Gavrielides offers a critical analysis of selected issues concerning the recourse to restorative justice in public law cases. His analysis spans victim-offender mediation, family group conferences (restorative conferencing), healing and sentencing circles, and community restorative boards. Such analysis suggests approaches that keep restorative justice at the local level and avoid standardization. Gavrielides concludes his analysis by suggesting that 'a mixed model of service provision through the state arm and community organizations seems to be the way forward, in terms of both increasing diversity and allowing completion, and avoiding a monopoly and a one size fits all approach'.

Carrie Menkel-Meadow's chapter brings to the reader a detailed investigation of hybrid and mixed processes. She argues that process pluralism is the appropriate way forward in developing means for resolving disputes. But at the same time, she identifies and assesses the empirical dangers and jurisprudential issues that might arise from such pluralism. Disputants and dispute resolution are varied in nature and inherently changeable; legal and moral principles, procedure, emotions, values and religion inevitably influence the parties in a dispute and its resolution. Menkel-Meadow therefore argues that hybridity is essential to meet the different settings, contexts and needs of disputants. She concludes with the observation that:

it may be that the greatest challenge to comparative dispute resolution (seeking both peace and justice) at the present time is to design processes where all three of these modes may co-exist in the same room at the same time, or whether we can try to consider a taxonomy of choice for considering which modes of conflict resolution or which forms of engagement are best used in what situations.

Zhao Yun looks at the nature and growth of ODR, noting its ever-increasing importance both domestically and in the international context, and looking at some of the important issues concerning the application of the principle of self-regulation in the field of ODR. He suggests that relying too heavily on self-regulation in ODR systems is problematic and presents issues for the future development of ODR. Although there have been attempts at drafting acceptable guidelines for the appropriate use of ODR internationally, shortcomings remain. Zhao Yun then offers some conclusions on how better to overcome the limitations in and lack of current regulation.

The chapters in Part VII examine approaches to dispute resolution in a variety of legal systems, societies and cultures. They show that disputes are developed, perceived and managed in ways that are culturally embedded and socially constructed. Indeed, variations in cultural and social approaches gain particular significance in a globalized world, in which disputants are increasingly drawn from diverse backgrounds. Even the move from informal to formal justice (and back again) is a cultural process which may require negotiations between several legal cultures: traditional, normative, international and global.

The chapters here are generally interdisciplinary in nature and focus on legal systems in Africa, Asia and South America. Looking at the regional examples analysed in this part, some common trends concerning processual issues more generally are to be found. These include debates about the institutionalization of dispute resolution methods, the juxtaposition of formal and informal methods, legal transplants of dispute resolution methods, and recourse to settlement as a way to convey social values and to protect communities. At the same time, 
differences regarding processual issues reside in the extent to which principles of access to justice inform the above debates and impact on the availability of, and recourse to, dispute resolution processes. The reader is encouraged to reflect on the economic and political factors that help to trigger legislative developments aimed at making the informal more formal and the formal more informal. Specifically, the chapters in this part of the book address the manner in which ideals and practices of formal and informal justice co-exist, are juxtaposed and are sometimes conflated. Further, the contributions explore pressures for modernization and institutionalization of informal justice, in some cases from the early nineteenth century onwards. As Laura Nader has suggested: 'we must ask what social, economic, and political forces work in the creation of a marginal law that plays a central role in this society?' (1984: 637). Indeed, most of the chapters which follow analyse the extent to which power dynamics are central to determining whether and how mechanisms of formal and informal justice interact. The chapters show that informal and formal co-exist and are often in tension - there is something of a continuous negotiation between formal and informal that legal systems and their legal cultures present.

It may be argued that there is a dispute resolution legal culture - both internal and external, to use the language of Lawrence Friedman (1975). The extent to which legal cultures influence the legal systems which they have helped to create is an important question. Also, our perception about culture's attitudes towards dispute resolution might be influenced by popular assumptions about that specific culture. Accordingly, the chapters remind us that disputes are about social relations, and that social relations influence disputes and their resolution. ${ }^{75}$ It follows that dispute resolution methods might aim to maintain and reshape social relations. Sometimes, religious impulses towards informalism are often leavened with elements of secular law, so that dispute resolution mechanisms might come to exhibit the results of pressure of both religious belief and secularization.

Most chapters in this part of the book develop by building on original empirical data and drawing on a variety of interdisciplinary sources. Interdisciplinary studies are indeed significant for any endeavour aimed at offering comparative analysis of legal systems and their legal cultures (Foster, Moscati and Palmer 2017). All the authors in this part seem to suggest the several ways in which the literature on dispute resolution and empirical data on informal justice in a variety of societies have relevance for mainstream jurisprudence and processual issues. The focus on regional case studies implicitly raises issues of globalization, and in particular about legal transplants and legal pluralism. Ultimately, the chapters reveal that dispute resolution is often about pursuing dialogues - between disputants, cultures, times and spaces - using a variety of languages and means.

The chapter by Fernanda Pirie entitled 'The Mirror of the Two Laws: A Treatise on Law from Medieval Tibet', reminds us that 'dispute resolution is a cultural process. It reflects the social norms and values of the context in which it is practised - ideas about justice, compensation, the role of punishment, and so on'. At the same time, through the analysis of dispute resolution, it is possible to understand the nature and dynamics of a community. Thus, the chapter offers insights not only into dispute resolution methods, but also into how such methods embody values and convey messages about right and wrong.

75 See comments above on Simmel; Felstiner (1974), Palmer and Roberts (2020). 
The chapter contributed by Mohamed Keshavjee considers how dispute resolution mechanisms have developed in Islamic cultures. By focusing on sulh - negotiated settlement - he introduces the reader to the Sunni and Shi'i branches of Islam, and then shows the extent to which religious authority has informed practices of dispute resolution. However, in explaining the principles and methods of dispute resolution, Keshavjee points out: 'Thus, Muslim dispute resolvers defer to the law of the land in those issues where they lack the necessary legal competence.' Consequently, not only is the religious practice of sulh shaped and reshaped according to the country in which a Muslim community lives; but more importantly, depending on the type of dispute, the degree of recourse to secular legal norms changes. This in turn encourages further thinking about the private and public divide debate. Keshavjee ends his chapter with a call for efforts to be refocused onto the higher purposes of Sharia. He concludes that such a refocusing, coupled with a readiness to refurbish traditional Islamic dispute resolution systems and bring them in line with the public laws of the various societies in which millions of Muslims are settled today, would enhance the value of ADR for the public good more generally.

Emilia Onyema's chapter analyses the impact of colonialism on the indigenous mechanisms of dispute resolution processes of West African states. She argues that litigation - brought in by colonial powers - has limited the traditional forms of dispute processing that operated in the pre-colonial communities of West African states, and that it remains the preferred dispute resolution mechanism. At the same time, imported ADR mechanisms as developed in the West are now spreading in West Africa. However, as suggested above, the co-existence of formal and informal methods is found in several cultures. So Onyema observes that several West African legal systems have legally recognized the recourse to traditional dispute resolution processes.

Kalindi Kokal explores dispute processing in a fishermen's village in the state of Maharashtra, western India. Her chapter considers the manner in which spaces of the state, such as police stations and state courts, were considered and used by the Kolī community in the village. Building on empirical data, she argues that 'such use of spaces and places of the state reveals another translation of state law ... and the manner in which it is optimized'. The 'space' at the core of this chapter is multi-dimensional in both its abstract and more tangible dimensions. But it also comprises different imaginations of space in between the spheres of the state and non-state. Thus, Kokal suggests, dispute processing represents an important site 'that reveals the forms of use of these spaces, which are in themselves expressions of the manner in which laws are constituted and interpreted'.

In their chapter, Dohyun Kim and Chulwoo Lee encourage the reader to reflect on the discrepancies created by cultural assumptions concerning harmony and litigiousness in South Korea. The authors, drawing on empirical data, show that patterns of litigation and the high litigation rate contradict the assumption that Koreans are averse to litigation and prefer non-adjudicative means of dispute resolution. Indeed, it appears that most Koreans are not keen to rely on mediation for the resolution of their disputes. Koreans rarely resort to private mediation or ADR services provided by non-state actors. In judicial practice, however, recourse to settlement is strongly promoted. As a result, a practice of 'mediation from above' has become highly institutionalized.

Moving to China, the chapter by Shen Wei examines the role of the Shanghai Commercial Mediation Centre in financial dispute resolution. Although the centre is located in a so-called Chinese harmonious society, with a strong emphasis on mediation as the preferred mode of 
handling disputes, it has struggled to secure success. Shen Wei surveys the causes of this limited success and explains that in China, the traditional attitude towards harmonious outcomes through mediation in dispute resolution has overlooked the need to deal effectively with the dynamics, methods and timing of financial transactions and the disputes that arise from them. Therefore, the chapter suggests that greater recourse to courts and litigation may well have the benefit of bridging the gap between preservation of traditional dispute resolution values on the one hand, and the need to deliver sophisticated processes that can cope with the current growth of more dynamic financial disputes on the other.

William Butler's chapter considers the post-Soviet Russian tentative recourse to mediation. The process of, and issues arising from, the legal institutionalization of mediation suggest that historically, mediation did not receive sufficient attention from the legislature. Attempts to institutionalize mediation have been undertaken even though many jurists are sceptical about the viability of mediation in Russia. Proposals have been advanced to extend state privileges to mediators or to eliminate conflicts between the Law on Mediation and other legislative acts, including procedural codes. Debate continues concerning the regulation and training of mediators. Butler believes that in the debate for and against institutionalization of and state involvement in mediation, there is substantial cultural reluctance to embrace mediation.

Aonghus Cheevers' chapter introduces the reader to developments of mediation in Ireland. His chapter engages with comparative legal studies discourse and analyses the Mediation Act 2017. It shows that legal transplants are indeed complex, but at the same time can be effective - in this case, success will depend on the extent to which foreign rules are examined, assessed and adjusted to Irish system and culture. He argues that 'in many ways, the development of the Mediation Act 2017, and the idea of voluntarism in Ireland, supports the idea that legal transplants [of ADR initiatives] can happen'.

Katrin Seidel's ethnographic account of dispute resolution mechanism in South Sudan raises questions concerning the co-existence of the local law of the various social communities and state law. The South Sudan Law Reform (Review) Commission - an independent constitutional body - has been established as a negotiation forum, and as tool of harmonization between the various customary law regimes and the statutory laws of South Sudan under a 'unity and diversity' approach. But the road to harmonization is characterized by continuous negotiations between local groups and state powers aimed at avoiding further conflicts among local authorities. Risks concerning the legitimacy - and the perceived legitimacy - of state actors might trigger conflict. Seidel points out that:

in order to progress with regard to state formation, it is important to establish normative and institutional frameworks. Constitutional recognition of local normative orders not only opens up spaces for negotiations, but also appears to be a crucial legal tool for dealing with the de facto only marginal influence of state (statutory) law.

The chapter by Anita Ferrara is a detailed analysis of the role of transitional justice mechanisms in Chile. These processes are conceptualized as mechanisms of conflict transformation in a deeply divided society. In particular, this chapter sheds light on the contribution that transitional justice mechanisms have made to Chilean society by confronting past abuses and 
restoring the national Convivencia.$^{76}$ Ferrara suggests that transitional justice mechanisms develop 'a national dialogue', offering 'spaces' and 'opportunities' for re-establishing a more inclusive national narrative over a contentious and divisive past. Through these mechanisms, private voices and experiences have the opportunity to be shared and become public - such visibility raises awareness, consciousness and coexistence.

\section{ACKNOWLEDGEMENTS}

We thank the authors who contributed chapters to this book: they have made it impressive in terms of coverage and depth. We are grateful to have had this opportunity to work with contributors and look forward to continuing to learn from their research and publications in the years to come.

We also wish to commemorate Aonghus Cheevers, a fine scholar who unexpectedly and sadly passed away earlier this year (2020).

\section{BIBLIOGRAPHY}

Abel, Richard L. (1973) 'A Comparative Theory of Dispute Institutions in Society', 8 Law \& Society Review 217-314.

Abel, Richard L. (1982) 'The Contradictions of Informal Justice', in Abel, R.L. (ed), The Politics of Informal Justice, Vol 1 The American Experience. New York: Academic Press.

Adams, Maurice and Jacco Bomhoff (eds) (2012) Practice and Theory in Comparative Law. Cambridge: Cambridge University Press.

Aeken, Koen van (2012) 'Civil court litigation and Alternative Dispute Resolution', in Clark, D.S. (ed) Comparative Law and Society. (Research Handbooks in Comparative Law). Cheltenham: Edward Elgar Publishing.

Agapiou, Andrew and Deniz Artan Ilter (eds) (2017) Court-Connected Construction Mediation Practice: A Comparative International Review. London and New York: Routledge.

Ali, Shahla F. (2013) Consumer Financial Dispute Resolution in a Comparative Context: Principles, Systems and Practice. Cambridge: Cambridge University Press.

Ali, Shahla F. (2018) Court Mediation Reform: Efficiency, Confidence and Perceptions of Justice. Cheltenham: Edward Elgar Publishing.

Ali, Shahla F. and Tom Ginsburg (eds) (2013) International Commercial Arbitration in Asia. Huntington: Juris. Third Edition.

Astor, Hilary and Christine M. Chinkin (2002) Dispute Resolution in Australia. Sydney: LexisNexis Butterworths. Second Edition.

Auerbach, Jerold S. (1983) Justice Without Law? New York and Oxford: Oxford University Press.

Bennett, Thomas. W. (2006) 'Comparative Law and African Customary Law', in Reimann, M. and R. Zimmermann (eds), The Oxford Handbook of Comparative Law. Oxford: Oxford University Press. First Edition.

Bennett, Thomas W. (2010) 'Legal Anthropology and Comparative Law: A Disciplinary Compromise?', 21 Stellenbosch Law Review 4-25.

Bennett, Thomas. W. (2019) 'Comparative Law and African Customary Law', in Reimann, M. and R. Zimmermann (eds), The Oxford Handbook of Comparative Law. Oxford: Oxford University Press. Second Edition.

76 Ferrara explains that 'Convivencia' is 'a state in which groups holding opposing views and opinions can live together while respecting each other's differences and resolve conflicts in a non-violent manner'. 
Besson, Samantha (2019) 'Comparative Human Rights Law', in Reimann, M. and R. Zimmermann (eds), The Oxford Handbook of Comparative Law. Oxford: Oxford University Press. Second Edition.

Bossy, John (1983) Disputes and Settlements: Law and Human Relations in the West. London and New York: Cambridge University Press.

Bradney, Anthony and Fiona Cownie (2000) Living Without Law: An Ethnography of Quaker Decision-Making, Dispute Avoidance, and Dispute Resolution. Aldershot: Ashgate \& Dartmouth. First Edition.

Bussani, Mauro and Ugo Mattei (2012) 'Dispositives versus Movies - the Inner Dynamics of the Law and its Comparative Account', in Bussani, M. and U. Mattei (eds) The Cambridge Companion to Comparative Law. Cambridge: Cambridge University Press.

Cadiet, Loïc, Burkhard Hess and Marta Requejo Isidro (eds) (2019) Privatizing Dispute Resolution: Trends and Limits. Baden-Baden: Nomos (Studies of the Max Planck Institute Luxembourg for International, European \& Regulatory Procedural Law. Volume 18).

Caplan, Patricia (ed) (1995) Understanding Disputes: The Politics of Argument. Oxford and Providence: Berg.

Cappelletti, Mauro and Bryant G. Garth (1978) 'Access to Justice: The Newest Wave in the Worldwide Movement to Make Rights Effective', 27 Buffalo Law Review 181-292.

Cappelletti, Mauro (ed) (1978 and 1979) Access to Justice. Alphen aan den Rijn: Sijthoff \& Noordhoff; Milan: Dott A. Giuffrè Editore.

Chan, Peter C.H. (2017) Mediation in Contemporary Chinese Civil Justice: A Proceduralist Diachronic Perspective. Leiden and Boston: Brill Nijhoff.

Chase, Oscar G. and Vincenzo Varano (2012) 'Comparative Civil Justice', in Bussani, M. and U. Mattei (eds), The Cambridge Companion to Comparative Law. Cambridge: Cambridge University Press.

Claxton, James M., Luke R. Nottage and Nobumichi Teramura (2019) 'Developing Japan as a Regional Hub for International Dispute Resolution: Dream Come True or Daydream?', 47 Journal of Japanese Law 109-31.

Cohen, Amy J. (2009) 'Revisiting Against Settlement: some Reflections on Dispute Resolution and Public Values', 78 Fordham Law Review 1143-70.

Comaroff, John and Simon Roberts (1981) Rules and Processes: The Cultural Logic of Dispute in an African Context. Chicago: University of Chicago Press.

Cotterrell, Roger (2019) 'Comparative Law and Legal Culture', in Reimann, M. and R. Zimmermann (eds), The Oxford Handbook of Comparative Law. Oxford: Oxford University Press. Second Edition.

Creutzfeldt, Naomi, Agnieszka Kubal and Fernanda Pirie (2016) 'Introduction: Exploring the Comparative in Socio-Legal Studies', 12 International Journal of Law in Context 377-89.

Creutzfeldt, Naomi (2018) Ombudsmen and ADR: A Comparative Study of Informal Justice in Europe. Cham: Palgrave Macmillan, Palgrave Socio-legal Studies.

Daniels, Caroline (2019) 'Alternative Dispute Resolution for European Consumers: A Question of Access to and Standards of Justice', in Cadiet, L., B. Hess and M. Isidro (eds), Privatizing Dispute Resolution. Baden-Baden: Nomos (Max Planck Institute Luxembourg for Procedural Law).

Davies, Weridy and Paul Fouracre (eds) (1986) The Settlement of Disputes in Early Medieval Europe. Cambridge: Cambridge University Press.

Delgado, Richard (1988) 'Review: ADR and the Dispossessed: Recent Books about the Deformalization Movement (Reviewed Works: Neighborhood Justice in Capitalist Society: The Expansion of the Informal State by Richard Hofrichter; Shadow Justice: The Ideology and Institutionalization of Alternatives to Court by Christine B. Harrington; Dispute Resolution by Stephen B. Goldberg, Eric D. Green, Frank E.A. Sander)', 13 Law \& Social Inquiry 145-54.

Dezalay, Yves and Bryant Garth (1995) 'Merchants of Law as Moral Entrepreneurs: Constructing International Justice from the Competition for Transnational Business Disputes', 29 Law \& Society Review 27-64.

Dezalay, Yves and Bryant Garth (1996) Dealing in Virtue. Chicago: University of Chicago Press.

Donahue, Charles (2019) 'Comparative Law before the Code Napoléon', in Reimann, M. and R. Zimmermann (eds) The Oxford Handbook of Comparative Law. Oxford: Oxford University Press. Second Edition.

Dragos, Dacian C. and Bogdana Neamtu (eds) (2014) Alternative Dispute Resolution in European Administrative Law. Berlin: Springer. 
Endicott, Timothy (2016) 'The Rule of Law and Online Dispute Resolution', (October 21, 2016) in Facheci A., T. Endicott and A.E. de Noriega, Online Dispute Resolution: virtud cívica digital, democracia y derecho (CEU Ediciones, Madrid 2017) 21-36, Available at SSRN: https://ssrn.com/abstract= 3278695 (last accessed 27 July 2020).

Esplugues, Carlos and Louis Marquis (2015) New Developments in Civil and Commercial Mediation: Global Comparative Perspectives. Cham, Heidelberg, New York, Dordrecht and London: Springer.

European Union Agency for Fundamental Rights and Council of Europe (2016) Handbook on European Law relating to Access to Justice. Luxembourg: Publications Office of the European Union.

Felstiner, William L.F. (1974) 'Influences of Social Organization on Dispute Processing', 9 Law \& Society Review 63-94.

Felstiner, William L.F., Richard L. Abel, Austin Sarat (1980-81) 'The Emergence and Transformation of Disputes: Naming, Blaming, Claiming', 15(3/4) Law \& Society Review 631-54 (Special Issue on Dispute Processing and Civil Litigation).

Fiss, Owen M. (1984) 'Against Settlement', 93(6) The Yale Law Journal 1073-90.

Fiss, Owen M. (1985) 'Out of Eden', 94(7) Yale Law Journal 1669-73.

Fitzpatrick, Peter (1993) 'The Impossibility of Popular Justice', in Merry, S.E. and N. Milner (eds) The Possibility of Popular Justice: A Case Study of American Community Mediation. Ann Arbor MI: University of Michigan Press.

Fordham Law Review (2009). Symposium: Against Settlement: Twenty-Five Years Later. Fordham University, School of Law; https://fordhamlawreview.org/symposiumcategory/emagainst-settlement -em-twenty-five-years-later/ (last accessed 27 July 2020).

Foster, Nicholas H.D. (2006) 'The Journal of Comparative Law: A New Scholarly Resource', 1(1) Journal of Comparative Law 1-12.

Foster, Nicholas H.D., Maria Federica Moscati and Michael Palmer (2017) Interdisciplinary Study and Comparative Law. London: Wildy, Simmonds \& Hill.

Friedman, Lawrence M. (1975) The Legal System: A Social Science Perspective. New York: Russell Sage Foundation.

Fu, Hualing and Michael Palmer (eds) (2017) Mediation in Contemporary China: Continuity and Change. London: Wildy, Simmonds \& Hill.

Fu, Hualing, Michael Palmer and Zhang Xianchu (eds) (2019) Transparency Challenges Facing China. London: Wildy, Simmonds \& Hill.

Fuller, Lon (2001) The Principles of Social Order: Selected Essays of Lon L. Fuller. Oxford: Hart. Revised edition with a new introduction and edited by Kenneth L. Winston. First edition, Durham: Duke University Press, 1981.

Galanter, Marc (1985) 'A Settlement Judge, Not a Trial Judge: Judicial Mediation in the United States', 12 Journal of Law \& Society 1-18.

Galanter, Marc (1992) 'Law Abounding: Legislation around the North Atlantic', 55(1) Modern Law Review 1-43.

Galanter, Marc (2010) 'Access to Justice in a World of Expanding Social Capability', 37 Fordham Urban Law Journal 115-28.

Gardner, John (2018) 'The Twilight of Legality', 43 Australasian Journal of Legal Philosophy 1-16.

Gilsenan, Michael (1976) 'Lying, Honor, and Contradiction', in Kapferer, Bruce (ed), Transaction and Meaning: Direction in the Anthropology of Exchange and Symbolic Behavior. Philadelphia: Institute for the Study of Human Issues. (Republished in 2016 in 6 Hau: Journal of Ethnographic Theory 497-525.)

Gordley, James (2006) 'Comparative Law and Legal History', in Reimann, M. and R. Zimmermann (eds) The Oxford Handbook of Comparative Law. Oxford: Oxford University Press. First Edition.

Gordley, James (2019) 'Comparative Law and Legal History', in Reimann, M. and R. Zimmermann (eds) The Oxford Handbook of Comparative Law. Oxford: Oxford University Press. Second Edition.

Graziadei, Michele (2006) 'Comparative Law as the Study of Transplants and Receptions', in Reimann, M. and R. Zimmermann (eds) The Oxford Handbook of Comparative Law. Oxford: Oxford University Press. First Edition.

Graziadei, Michele (2019) 'Comparative Law, Legal Transplants, and Receptions', in Reimann, M. and R. Zimmermann (eds) The Oxford Handbook of Comparative Law. Oxford: Oxford University Press. Second Edition. 
Greenhouse, Carol J. (1986) Praying for Justice: Faith, Order, and Community in an American Town. Ithaca: Cornell University Press.

Greenhouse Carol J. (1989) 'Interpreting American Litigiousness', in Starr, J. and J.F. Collier (eds) History and Power in the Study of Law: New Directions in Legal Anthropology. Ithaca: Cornell University Press.

Grillo, Trina (1991) 'The Mediation Alternative: Process Dangers for Women', 100 Yale Law Journal $1545-1610$.

Großfeld, B. (2003) 'Comparatists and Languages', in Legrand, P. and R. Munday (eds) Comparative Legal Studies: Traditions and Transitions. Cambridge: Cambridge University Press.

Gu, Weixia (2012) Arbitration in China: Regulation of Arbitration Agreements and Practical Issues. Hong Kong: Thomson Reuters.

Gulliver, Philip H. (1961): 'Land Shortage, Social Change, and Social Conflict in East Africa', 5(1) Journal of Conflict Resolution 16-26.

Gulliver, Philip H. (1963) Social Control in an African Society (A Study of the Arusha: Agricultural Masai of Northern Tanganyika). London: Routledge \& Kegan Paul.

Gulliver, Philip H. (1969a). Dispute Settlement without Courts: The Ndendeuli of Southern Tanzania. In L. Nader (ed.), Law in Culture and Society. Chicago: Aldine Press.

Gulliver, Philip H. (1969b) 'Introduction: Case Studies of Law in non-Western Societies', in Nader, L. (ed), Law in Culture and Society. Chicago: Aldine Press.

Gulliver, Philip H. (1973) 'Dispute Settlement by Negotiations: Towards a General Model', 7 Law \& Society Review 667-91.

Gulliver, Philip H. (1974) 'Negotiations and Mediation', Law \& Society Papers 3. Berkeley: University of California Law \& Society Program.

Gulliver, Philip H. (1975) 'An Arusha Land Dispute', in Karp, M. (ed), African Perspectives. Boston: African Studies Program, Boston University.

Gulliver, Philip H. (1977) 'On Mediators', in Hamnett, I. (ed), Law and Social Anthropology. Association of Social Anthropologists Monographs (ASA) Vol 14. London: Academic Press.

Gulliver, Philip H. (1978) 'Process and Decision', in Gulliver, P.H. (ed), Cross-Examinations: Essays in Memory of Max Gluckman. Leiden: Brill.

Gulliver, Philip H. (1979) Disputes and Negotiations: A Cross Cultural Perspective. New York and London: Academic Press.

Gulliver, Philip H. (1986) 'Negotiations and Arbitration', in Encyclopedia of Social Science. London: Routledge.

Gulliver, Philip H. (1988) 'Anthropological Contributions to the Study of Negotiations', 4 Negotiation Journal 247-55.

Gulliver, Philip H. (1996) 'On Avoidance', in Parkin, D.J., L. Caplan and H.J. Fisher (eds) The Politics of Cultural Performance. Providence: Berghahn Books.

Hampshire, Stuart (1983) Morality and Conflict. Cambridge: Harvard University Press.

Hampshire, Stuart (1989) Innocence and Experience. London: Allen Lane

Hampshire, Stuart (1996) Justice Is Conflict: The Soul and the City, The Tanner Lectures on Human Values. (Delivered at Harvard University, 30-31 October 1996.)

Hampshire, Stuart (1999) Justice is Conflict. London: Duckworth. (Expanded and revised version of the Tanner Lectures, 1996.)

Harding, Andrew and Esin Örücü (2002) Comparative Law in the 21st Century. London: Kluwer Academic.

Hodges, Christopher, Iris Benöhr and Naomi Creutzfeldt (eds) (2012) Consumer ADR in Europe. London: Bloomsbury Publishing.

Hodges, Christopher, Naomi Creutzfeldt, Felix Steffek and Eline Verhage (2016) ADR and Justice in Consumer Disputes in the EU. Oxford: The Foundation for Law, Justice \& Society.

Hollander, Mindy R. (2017) 'Overcoming the Achilles' Heel of Consumer Protection: Limiting Mandatory Arbitration Clauses in Consumer Contracts', 46(1) Hofstra Law Review 363-98.

Hopt, Klaus J. and Felix Steffek (eds) (2013) Mediation: Principles and Regulation in Comparative Perspective. Oxford: Oxford University Press.

Huang, Philip C. C. (1993) 'Between Informal Mediation and Formal Adjudication: the Third Realm of Justice in Qing China’, 19(3) Modern China 251-98. 
Kressel, Kenneth (1985) The Process of Divorce: How Professionals and Couples Negotiate Settlement. New York: Basic Books.

Kronman, Anthony (1993) The Lost Lawyer: Failing Ideals of the Legal Profession. Cambridge: The Belknap Press of Harvard University.

Legrand, Pierre (1997) 'The Impossibility of Legal Transplants', 4 Maastricht Journal of European \& Comparative Law 111-24.

Lerman, Lisa G. (1984) 'Mediation of Wife Abuse Cases: The Adverse Impact of Informal Dispute Resolution on Women', 7 Harvard Women's Law Journal 57-133.

Lindblom, Per Henrik (2017) Progressive Procedure: The Role of Courts, Access to Justice, Group Actions, Complex Litigation and Alternative Dispute Resolution in Comparative Perspective: Twelve Essays 1985-2015. Uppsala: Iustus Förlag.

Liu, Qiao, Wenhua Shan and Xiang Ren (eds) (2016) China and International Commercial Dispute Resolution. Lieden and Boston: Brill Nijhoff.

Llewellyn Karl N. and E. Adamson Hoebel (1941) The Cheyenne Way: Conflict and Case Law in Primitive Jurisprudence. Norman: University of Oklahoma Press.

Llewellyn, Karl N. (2008) Jurisprudence: Realism in Theory and Practice. (With introduction by James J. Chriss.) New Brunswick: Transaction Publishers.

Luban, David (1995) 'Settlements and the Erosion of the Public Realm', 83 Georgetown Law Journal 2619-62.

Macleod, Sonia and Christopher Hodges (eds) (2017) Redress Schemes for Personal Injuries. Oxford and Portland: Hart Publishing.

Malinowski, Bronislaw (1922) Argonauts of the Western Pacific. London: Routledge \& Kegan Paul; New York: E.P. Button.

Margalit, Avishai (2010) On Compromise and Rotten Compromises. Princeton: Princeton University Press.

Mattei, Ugo and Laura Nader (2008) Plunder: When the Rule of Law is Illegal. Oxford: Blackwell Publishing.

Mauss, Marcel (1990 [1925]) The Gift: The Form and Reason for Exchange in Archaic Societies (trans. Hall, W.D.). London: Routledge.

McCluskey, Martha (2016) 'Forced Arbitration Clauses Deny Justice to Consumers', Centre For Progressive Reform, at https://cpr-assets.s3.amazonaws.com/documents/Forced_Arbitration EditMemo_050516.pdf (last accessed 27 July 2020).

Mehrotra, A.K. (2001) 'Law and the Other: Karl N. Llewellyn, Cultural Anthropology, and the Legacy of The Cheyenne Way', 26(3) Law \& Social Inquiry 741-76.

Menkel-Meadow, Carrie J. (1985a) 'The Transformation of Disputes by Lawyers: What the Dispute Paradigm Does and Does Not Tell Us', 1985 Journal of Dispute Resolution 25-44.

Menkel-Meadow, Carrie (1985b) 'For and Against Settlement: Uses and Abuses of the Mandatory Settlement Conference', 33 UCLA Law Review 485-514.

Menkel-Meadow, Carrie J. (1995) 'Whose Dispute Is It Anyway? A Philosophical and Democratic Defense of Settlement (In Some Cases)', 83 Georgetown Law Journal 2663-96.

Menkel-Meadow, Carrie J. (2000) 'Mothers and fathers of invention: The intellectual founders of ADR', 16 Ohio State Journal of Dispute Resolution 1-37.

Menkel-Meadow, Carrie J. (2010) 'Compromise, Negotiation, and Morality’ 26(4) Negotiation Journal 483-99.

Menkel-Meadow, Carrie J., Lela Love, Andrea Schneider and Jean Sternlight (2018) Dispute Resolution: Beyond the Adversarial Model. New York: Aspen. Fourth Edition.

Menkel-Meadow, Carrie J. and Michael Wheeler (eds) (2004) What's Fair? Ethics for Negotiators. San Francisco: Jossey Bass-Wiley.

Merry, Sally Engle (1993) 'Sorting Out Popular Justice', in Merry, S.E. and N. Milner (eds) The Possibility of Popular Justice: A Case Study of American Community Mediation. Ann Arbor: University of Michigan Press.

Micklitz, Hans-W. and Genevieve Saumier (2018). Enforcement and Effectiveness of Consumer Law. Cham, Switzerland: Springer. Oxford: Oxford University Press.

Moore, Sally F. (1995) 'Imperfect Communications', in Caplan, P. (ed) Understanding Disputes: The Politics of Argument. Oxford and Providence: Berg. 
Moscati, Maria Federica (2015) Same-Sex Couples and Mediation in the EU (edited) for the European Commission - Directorate General Civil Justice - Project: Litigious Love: Same-Sex Couples and Mediation in the EU. London: Wildy, Simmonds \& Hill.

Nader, Laura (1984) 'The Recurrent Dialectic Between Legality and its Alternatives: The Limitations of Binary Thinking: Review of Justice Without Law? By Jerold S. Auerbach. New York: Oxford University Press, 1983', 132 University of Pennsylvania Law Review 621-45.

Nader, Laura (1990) Harmony Ideology: Injustice and Control in a Mountain Zapotec Village. Stanford: Stanford University Press.

Nader, Laura (1993) 'Controlling Processes in the Practice of Law: Hierarchy and Pacification in the Movement to Re-Form Dispute Ideology', 9 Ohio State Journal on Dispute Resolution 1-25.

Nader, Laura (1995) 'Civilization and its Negotiations', in Caplan, P. (ed), Understanding Disputes: The Politics of Argument. Oxford and Providence: Berg.

Nader, Laura and Harry Todd (1978) The Disputing Process: Law in Ten Societies. New York: Columbia University Press.

Nottage, Luke (2019) 'Development of Comparative Law in Japan', in Reimann, M. and R. Zimmermann (eds) The Oxford Handbook of Comparative Law. Oxford: Oxford University Press. Second Edition.

Otero Garcia-Castrillon, Carmen (2011) 'International Litigation Trends in Environmental Liability: European Union-United States comparative perspective', 7(3) Journal of Private International Law 551-82.

Palmer, Michael (2006) 'On Galloping Horses and Picking Flowers. A review of H. Patrick Glenn, "Legal Traditions of the World: Sustainable Diversity in Law",' 1(1) Journal of Comparative Law $165-70$.

Palmer, Michael (2014) 'Formalisation of Alternative Dispute Resolution Processes: Some Socio-Legal Thoughts', in Zekoll, J., M. Balz and I. Amelung (eds) Formalisation and Flexibilisation in Dispute Resolution. Leiden: Brill.

Palmer, Michael and Simon Roberts (1998) Dispute Processes: ADR and the Primary Forms of Decision Making. London: Butterworths. First Edition.

Palmer, Michael and Simon Roberts (2020) Dispute Processes: ADR and the Primary Forms of Decision Making. Cambridge: Cambridge University Press. Third Edition.

Peters, Christopher J. (2011) A Matter of Dispute: Morality, Democracy, and Law. Oxford. Oxford University Press.

Postema, Gerald J. (2019) Bentham and the Common Law Tradition. Oxford and New York: Clarendon Press.

Radin, Margaret Jane (2013) Boilerplate: The Fine Print, Vanishing Rights, and the Rule of Law. Princeton and Oxford: Princeton University Press.

Raz, Joseph (2009) Between Authority and Interpretation: On the Theory of Law and Practical Reason. Oxford and New York: Oxford University Press.

Reimann, Mathias and Reinhard Zimmermann (eds) (2006) The Oxford Handbook of Comparative Law. Oxford: Oxford University Press. First Edition.

Reimann, Mathias and Reinhard Zimmermann (eds) (2019) The Oxford Handbook of Comparative Law. Oxford: Oxford University Press. Second Edition.

Relis, Tamara (2009) Perceptions in Litigation and Mediation: Lawyers, Defendants, Plaintiffs, and Gendered Parties. Cambridge: Cambridge University Press.

Remáč, Milan (2014) Coordinating Ombudsmen and the Judiciary: A Comparative view on the Relations between Ombudsmen and the Judiciary in the Netherlands, England and the European Union. Cambridge, Antwerp and Portland: Intersentia.

Resnik, Judith (2003) 'For Owen M. Fiss: Some Reflections on the Triumph and the Death of Adjudication', 58 University of Miami Law Review 173-200.

Resnik, Judith (2015) 'The Contingency of Openness in Courts: Changing the Experiences and Logics of the Public's Role in Court-based ADR', 15 Nevada Law Journal 1631-88.

Reyes, Anselmo and Gu Weixia (2018) The Developing World of Arbitration: A Comparative Study of Arbitration Reform in the Asia Pacific. Oxford: Hart.

Reynolds, Michael (2020a) 'In Chancery: The Genesis of Micro Caseflow Management', 1(2) Amicus Curiae 165-200 (New Series). 
Reynolds, Michael (2020b) 'Judicial Experiments in Caseflow Management 1920-70', 1(3) Amicus Curiae 389-417.

Riles, Annelise (2006) 'Comparative Law and Socio-legal Studies', in Reimann, M. and R. Zimmermann (eds) The Oxford Handbook of Comparative Law. Oxford: Oxford University Press. First Edition.

Riles, Annelise (2019) 'Comparative Law and Socio-legal Studies', in Reimann, M. and R. Zimmermann (eds) The Oxford Handbook of Comparative Law. Oxford: Oxford University Press. Second Edition.

Roberts, Marian (2014a) a-z of mediation. Basingstoke: Palgrave Macmillan.

Roberts, Marian (2014b) Mediation in Family Disputes: Principles of Practice. Farnham and Burlington: Ashgate Publishing Limited. Fourth Edition.

Roberts, Marian (2016) 'A View from the Coal Face: Interdisciplinary Influences on Family Mediation in the United Kingdom', 9(2) Journal of Comparative Law 108-18.

Roberts, Simon (1983) 'Mediation in Family Disputes', 46(5) Modern Law Review 537-57.

Roberts, Simon (1998) 'Against Legal Pluralism: Some Reflections on the Contemporary Enlargement of the Legal Domain', 30(42) The Journal of Legal Pluralism and Unofficial Law 95-106.

Roberts, Simon and Michael Palmer (2005) Dispute Processes: ADR and the Primary Forms of Decision Making. Cambridge and New York: Cambridge University Press.

Roberts, Simon (2008) 'Legal Pluralism', in Cane, P. and J. Conaghan (eds) (2009) The New Oxford Companion to Law. Oxford: Oxford University Press (published online 2009).

Roberts, Simon (2013) A Court in the City: Civil and Commercial Litigation in London at the Beginning of the 21st Century. London: Wildy, Simmonds \& Hill.

Rosen, Lawrence (2006) Law as Culture: An Invitation. Princeton and Oxford: Princeton University Press.

Ruskola, Teemu (2012) 'The East Asian Legal Tradition', in Bussani, M. and U. Mattei (eds) Cambridge Companion to Comparative Law. Cambridge: Cambridge University Press.

Sahlins, Marshal (1965) 'On the Sociology of Primitive Exchange', in Banton, M. (ed), The Relevance of Models for Social Anthropology. Association of Social Anthropologists Monographs (ASA) Vol 1. London: Tavistock.

Samuel, Geoffrey (2019) 'Can Social Science Theory Aid the Comparative Lawyer in Understanding Legal Knowledge?', 14(2) The Journal of Comparative Law 311-30.

Santos, Boaventura de Sousa (1982) 'Law and Community: The Changing Nature of State Power in Late Capitalism', in Abel, R.L. (ed), The Politics of Informal Justice, Vol 1 The American Experience. New York: Academic Press.

Schultz, Thomas (2016) 'Celebrating 20 Years of "Dealing in Virtue", 7(3) Journal of International Dispute Settlement 531-33.

Siems, Mathias (2014) Comparative Law. Cambridge: Cambridge University Press. First Edition.

Siems, Mathias (2018) Comparative Law. Cambridge: Cambridge University Press. Second Edition.

Simmel, Georg ([1921] 1955) Conflict and the Web of Group Affiliations. New York: The Free Press.

Simmel, Georg (1950) The Sociology of Georg Simmel. Translated, edited and introduced by Wolff, K.H. New York: Free Press of Glencoe.

Simmel, Georg (2009) 'Conflict', in Simmel, G., Sociology: Inquiries into the Construction of Social Forms, Volume 1. Leiden and Boston: Brill.

Townsley, Brooke (2016) Understanding Justice: An Enquiry into Interpreting in Civil Justice and Mediation. London: Middlesex University.

Twining, William (1993a) 'Theories of Litigation, Procedure and Dispute Settlement', 56 Modern Law Review 380-92.

Twining, William (1993b) 'The Idea of Juristic Method: A Tribute to Karl Llewellyn', 48 University of Miami Law Review 119-58.

Twining, William (2019) Jurist In Context: A Memoir. Cambridge and New York: Cambridge University Press.

Ubink, J. (2016) 'Access vs. justice: Customary Courts and Political Abuse Lessons from Malawi's Local Courts Act', 64(3) American Journal of Comparative Law 745-84.

White, James J. (1980) 'Machiavelli and the Bar: Ethical Limitations on Lying in Negotiation', 1980 American Bar Foundation Research Journal 926-38. 


\section{Comparative dispute resolution}

Willamette Journal of International Law and Dispute Resolution (2002) 'The Fiftieth Anniversary Meeting of the American Society of Comparative Law - Comparative Dispute Resolution: A New Look'. Vol 10(1) Willamette University College of Law, Salem, Oregon.

Wilmot-Smith, Frederick (2014) 'Necessity or Ideology?', 36(21) London Review of Books, 6 November 2014.

Woolf, Lord Harry (1996) Access to Justice: Final report to the Lord Chancellor on the civil justice system in England and Wales. London: HMSO.

Zekoll, Joachim (2006) 'Comparative Civil Procedure', in Reimann, M. and R. Zimmermann (eds) The Oxford Handbook of Comparative Law. Oxford: Oxford University Press. First Edition.

Zekoll, Joachim (2019) 'Comparative Civil Procedure', in Reimann, M. and R. Zimmermann (eds) The Oxford Handbook of Comparative Law. Oxford: Oxford University Press. Second Edition.

Zekoll, Joachim, Moritz Balz and Iwo Amelung (eds) (2014) Formalisation and Flexibilisation in Dispute Resolution. Leiden and Boston: Brill.

Zhang, Taisu (2019) 'Development of Comparative Law in China', in Reimann, M. and R. Zimmermann (eds) The Oxford Handbook of Comparative Law. Oxford: Oxford University Press. Second Edition.

Zhou, Ling (2013) 'The Independent Director System and its Legal Transplant into China', 6(2) Journal of Comparative Law 262-91.

Zhou, Ling (2020) Access to Justice for the Chinese Consumer: Handling Consumer Disputes in Contemporary China. Oxford and Portland: Hart. 